\title{
The performance of small scale multi-generation technologies in achieving cost-optimal and zero-energy office building solutions
}

\section{Citation for published version (APA):}

Mohamed, A., Hamdy, M., Hasan, A., \& Sirén, K. (2015). The performance of small scale multi-generation technologies in achieving cost-optimal and zero-energy office building solutions. Applied Energy, 152, 94-108. https://doi.org/10.1016/j.apenergy.2015.04.096

DOI:

10.1016/j.apenergy.2015.04.096

Document status and date:

Published: 01/01/2015

\section{Document Version:}

Publisher's PDF, also known as Version of Record (includes final page, issue and volume numbers)

\section{Please check the document version of this publication:}

- A submitted manuscript is the version of the article upon submission and before peer-review. There can be important differences between the submitted version and the official published version of record. People interested in the research are advised to contact the author for the final version of the publication, or visit the DOI to the publisher's website.

- The final author version and the galley proof are versions of the publication after peer review.

- The final published version features the final layout of the paper including the volume, issue and page numbers.

Link to publication

\footnotetext{
General rights

- You may freely distribute the URL identifying the publication in the public portal. follow below link for the End User Agreement:

www.tue.nl/taverne

\section{Take down policy}

If you believe that this document breaches copyright please contact us at:

openaccess@tue.nl

providing details and we will investigate your claim.
}

Copyright and moral rights for the publications made accessible in the public portal are retained by the authors and/or other copyright owners and it is a condition of accessing publications that users recognise and abide by the legal requirements associated with these rights.

- Users may download and print one copy of any publication from the public portal for the purpose of private study or research.

- You may not further distribute the material or use it for any profit-making activity or commercial gain

If the publication is distributed under the terms of Article $25 \mathrm{fa}$ of the Dutch Copyright Act, indicated by the "Taverne" license above, please 


\section{Elsevier Editorial System(tm) for Applied Energy Manuscript Draft}

\section{Manuscript Number: APEN-D-15-00611R1}

Title: The performance of small scale multi-generation technologies in achieving cost-optimal and zero-energy office building solutions

Article Type: Original Paper

Keywords: EPBD recast; life-cycle cost; biomass; combined heating and power (CHP); combined cooling heating and power (CCHP); zero-energy office building

Corresponding Author: Mr. Ayman Abdelhamed Mostafa Mohamed, MSc

Corresponding Author's Institution: Aalto Univeristy

First Author: Ayman Abdelhamed Mostafa Mohamed, MSc

Order of Authors: Ayman Abdelhamed Mostafa Mohamed, MSc; Mohamed Hamdy ; Ala Hasan ; Kai Sirén

Abstract: This study investigates the economic viability of small-scale, multi-generation systems (combined heat and power (CHP), combined cooling, heating, and power (CCHP)), along with conventional heating and cooling systems combining sixteen heating/cooling energy generation systems (H/C-EGSs). The Energy Performance of Buildings Directive (EBPD) comparative framework methodology is followed. The local cost-optimal solution for an office building, in Helsinki, Finland is determined for each H/C-EGS as well as the global cost-optimum. The suggested energy efficiency measures get 144 building combinations, and alongside the H/C-EGSs, altogether 2304 cases. The results show that the global cost-optimum belongs to the ground source heat pump with free ground cooling. The investigated biomass-based CHPs are economically viable only with high overall efficiency and low power-to-heat ratio due to both low investment and operational costs. The biomass-based CCHPs do not have economic or environmental benefits over the biomass-based CHPs due to the significant increase entailed of both investment and operational costs. The fossil fuel-based CHPs with high operational costs are the worst solutions economically and environmentally. Extending the cost optimal solutions by a photovoltaic panels system yields the net zero-energy office building with minimum life-cycle costs as well. 
Highlights (for review)
Highlights
- The cost-optimal solutions for a new office building in Finland are obtained.
- $\quad$ The EBPD comparative framework methodology is followed.
- Biomass CHPs with high overall efficiency and low P/H ratio are economically viable.
- Biomass CCHPs do not have economic or environmental benefits over biomass CHPs.

Highlights (for review)
Highlights
- The cost-optimal solutions for a new office building in Finland are obtained.
- $\quad$ The EBPD comparative framework methodology is followed.
- Biomass CHPs with high overall efficiency and low P/H ratio are economically viable.
- Biomass CCHPs do not have economic or environmental benefits over biomass CHPs.

Highlights (for review)
Highlights
- The cost-optimal solutions for a new office building in Finland are obtained.
- $\quad$ The EBPD comparative framework methodology is followed.
- Biomass CHPs with high overall efficiency and low P/H ratio are economically viable.
- Biomass CCHPs do not have economic or environmental benefits over biomass CHPs.

Highlights (for review)
Highlights
- The cost-optimal solutions for a new office building in Finland are obtained.
- $\quad$ The EBPD comparative framework methodology is followed.
- Biomass CHPs with high overall efficiency and low P/H ratio are economically viable.
- Biomass CCHPs do not have economic or environmental benefits over biomass CHPs.

Highlights (for review)
Highlights
- The cost-optimal solutions for a new office building in Finland are obtained.
- $\quad$ The EBPD comparative framework methodology is followed.
- Biomass CHPs with high overall efficiency and low P/H ratio are economically viable.
- Biomass CCHPs do not have economic or environmental benefits over biomass CHPs.

Highlights (for review)
Highlights
- The cost-optimal solutions for a new office building in Finland are obtained.
- $\quad$ The EBPD comparative framework methodology is followed.
- Biomass CHPs with high overall efficiency and low P/H ratio are economically viable.
- Biomass CCHPs do not have economic or environmental benefits over biomass CHPs.

(1)

Ext 


\title{
The performance of small scale multi-generation technologies in achieving cost-optimal
} and zero-energy office building solutions

\author{
Ayman Mohamed ${ }^{\text {a* }}$, Mohamed Hamdy ${ }^{\text {a,b }}$, Ala Hasan ${ }^{\mathrm{c}}$, Kai Sirén ${ }^{\mathrm{a}}$ \\ ${ }^{\text {a }}$ Aalto University School of Engineering, Department of Energy Technology, P.O. Box 14400, FI-00076 Aalto, Finland. \\ ${ }^{\mathrm{b}}$ Eindhoven University of Technology, Department of the Built Environment, Building Physics and Services, Den Dolech \\ 2, 5612 AZ, Eindhoven, The Netherlands. \\ ${ }^{c}$ VTT Technical Research Centre of Finland, Espoo P.O. Box 1000, FI-02044 VTT, Finland. \\ " Corresponding author. Tel.: +358 50431 5774; fax: +358 947023418. \\ E-mail address: ayman.mohamed@aalto.fi, aymansarwah@gmail.com (A. Mohamed)
}

\section{Abstract}

This study investigates the economic viability of small-scale, multi-generation systems (combined heat and power (CHP), combined cooling, heating, and power (CCHP)), along with conventional heating and cooling systems combining sixteen heating/cooling energy generation systems (H/C-EGSs). The Energy Performance of Buildings Directive (EBPD) comparative framework methodology is followed. The local cost-optimal solution for an office building, in Helsinki, Finland is determined for each H/C-EGS as well as the global cost-optimum. The suggested energy efficiency measures get 144 building combinations, and alongside the H/C-EGSs, altogether 2304 cases. The results show that the global costoptimum belongs to the ground source heat pump with free ground cooling. The investigated biomass-based CHPs are economically viable only with high overall efficiency and low power-to-heat ratio due to both low investment and operational costs. The biomass-based CCHPs do not have economic or environmental benefits over the biomass-based CHPs due to the significant increase entailed of both investment and operational costs. The fossil fuel-based CHPs with high operational costs are the worst solutions economically and environmentally. Extending the cost optimal solutions by a photovoltaic panels system yields the net zero-energy office building with minimum life-cycle costs as well.

\section{Keywords}

EPBD recast; life-cycle cost; biomass; combined heating and power (CHP); combined cooling heating and power (CCHP); zero-energy office building 
Abbreviations:

\begin{tabular}{|c|c|}
\hline $\mathrm{AC}$ & Absorption chiller \\
\hline BSSP & Building service system package \\
\hline CAV & Constant air volume \\
\hline CCHP & Combined cooling, heating and power \\
\hline CHP & Combined heat and power \\
\hline $\mathrm{CO}_{2}$-eq & $\mathrm{CO}_{2}$ equivalent emissions \\
\hline $\mathrm{COP}$ & Coefficient of performance [-] \\
\hline DC & District cooling \\
\hline DH & District heating \\
\hline $\mathrm{dLCC}$ & Incremental life-cycle cost $\left[\mathrm{\epsilon} / \mathrm{m}^{2}\right]$ \\
\hline EEM & Energy efficiency measure \\
\hline EGS & Energy Generation system \\
\hline EPBD & Energy Performance of Building Directive \\
\hline GC & Ground cooling \\
\hline GHG & Greenhouse gases \\
\hline GSHP & Ground source heat pump \\
\hline $\mathrm{H} / \mathrm{C}$ & Heating/cooling \\
\hline HVAC & Heating ventilation and air conditioning \\
\hline ICE & Internal combustion engine \\
\hline IFGT & Indirect fire gas turbine \\
\hline LCC & life-cycle cost $\left[€ / \mathrm{m}^{2}\right]$ \\
\hline MS & Member states \\
\hline $\mathrm{mT}$ & Micro-turbine \\
\hline NG & Natural gas \\
\hline nZEB & Nearly zero-energy building \\
\hline NZEB & Net zero-energy building \\
\hline $\mathrm{O} \& \mathrm{M}$ & Operation and maintenance \\
\hline ORC & Organic Rankine cycle \\
\hline $\mathrm{P} / \mathrm{H}$ & Power to heat ratio \\
\hline PB & Pellet boiler \\
\hline $\mathrm{PE}$ & Primary energy \\
\hline PV & Photovoltaic panels \\
\hline $\mathrm{Q}_{\mathrm{c}}$ & thermal cooling capacity $[\mathrm{kW}]$ \\
\hline $\mathrm{Q}_{\mathrm{h}}$ & thermal heating capacity [kW] \\
\hline RET & Renewable energy technology \\
\hline SE & Stirling engine \\
\hline SFP & Specific fan power $\left[\mathrm{kW} /\left(\mathrm{m}^{3} / \mathrm{s}\right)\right]$ \\
\hline SHGC & Solar heat gain coefficient \\
\hline SPC & Space cooling demand $\left[\mathrm{kWh} / \mathrm{m}^{2} \mathrm{a}\right]$ \\
\hline SPH & Space heating demand $\left[\mathrm{kWh} / \mathrm{m}^{2} \mathrm{a}\right]$ \\
\hline VAV & Variable air volume \\
\hline VCR & Vapor compression refrigeration cooling system \\
\hline
\end{tabular}

\section{Introduction}

30 In order to reach the EU target of 20-20-20 (20\% GHG emissions reduction, 20\% increase of renewable energy and 20\%

31 increase in energy efficiency by 2020 from 1990 levels), the building sector has to be looked into, since the building energy 
needs in the European Union represent $40 \%$ of the overall energy consumption [1].The Energy Performance of Building

Directive 2010/31/EU, (EPBD) recast [2] specified that by the end of 2020, all new buildings shall be "nearly zero-energy buildings" (nZEB). As stipulated in this directive, all Member States (MS) shall ensure that minimum energy performance requirement achieving cost-optimal levels has to be set using a comparative methodology framework. The methodology framework was published as EU supplementary EBPD recast in 2012 as "Guidelines accompanying Commission Delegated Regulation (EU) No 244/2012 of 16 January 2012 supplementing Directive 2010/31/EU “ [3]. In May 2012, Finland submitted the minimum energy performance requirements for calculating cost-optimal levels report to the EU [4]. This report shows the cost-optimal of the minimum energy performance of new residential and commercial buildings built in accordance with the current Finnish building regulations D3-2012 [5] and D5 2012 [6] as well as existing buildings. The multi-generation systems including cogeneration heat and power (CHP) and tri-generation system (which is also defined as combined cooling, heating, and power (CCHP)) were not implemented in the Finnish report [4].

Several researches in Europe focused on a combination of building energy performance and cost analysis. Since the EPBD recast has been raised recently, a limited number of current studies refer directly to the objectives of the EPBD recast and related concepts. The implementation of the EPBD recast to determine the energy performance requirement under national perspectives is conducted and submitted by EU Member States as well as in some articles. Before publishing the EU supplementary EBPD recast [3], several studies tried to investigate the cost-optimal levels of minimum energy performance requirements such as [7]. Regarding the calculation method used to evalute the minimim energy requirements achieving the cost-opimal levels within the comparative methodology framework, the developed optimization techniques were presented by [8] applied to new single family house and [9] applied to the retrofitting of existing office buildings. Regarding the national polices and perspectives comparing with the EPBD requirements, Turkey as an EU Member Candidate, the adaptation of cost-optimal calculations under national circumstances and Mediterranean climates of Turkey using an existing office building is presented in [10]. Most of the aforementioned and similar studies investigated the building elements without changing the supply systems or with limited conventional systems.

The CHP as a proven and reliable form of technology provides various energetic, economic, and environmental advantages compared to the separate production of heat and power at the large and district levels. Various fuels can be supplied to the CHP systems such as natural gas (NG), diesel, peats, biogas, and biomass (wood). The biomass and biogas are considered renewable energy sources. Implementing small scale (in the 30 - $2000 \mathrm{kWe}$ range [11]) biomass-based CHP as a supply 
investigation of implementing biomass-based CHPs was carried out by $[12,13]$. Some studies investigated the biomassbased CCHP where the biomass-based CHP was coupled with thermally-activated cooling technology [14,15]. Meanwhile the net zero energy building (NZEB) definition is raised, the biomass-based CHP systems were investigated as a main energy supply system in [16,17]. Moreover, the energy matching capability of the micro-scale bio-syngas- and natural gas (NG)-based CHP systems operated under thermal and electrical tracking strategies, fulfilling NZEB balance are investigated in $[18,19]$. None of these studies looked at the cost-optimal levels for the minimum energy performance as a primary objective of the EBPD recast for multi-generation systems.

The main objective of this study is to find the local cost-optimal level for each heating/cooling energy generation system package (H/C-EGS) implemented on a representative new office building in Finland using the comparative methodology framework as well as the global cost-optimal level which is the minimum cost-optimal level among all H/C-EGSs. The H/C-EGSs are illustrated in Section 3.2, consisting of five conventional systems, four different biomass-based CHPs with a vapor compression refrigeration (VCR) system, four biomass-based CCHP with same technologies of the biomass-based CHP but coupled with absorption chiller (AC), and three fossil fuel-based CHPs with a VCR. The new office building is the same reference office building used in the Finnish report [4], selected as a representative office building built in accordance with the current Finnish building regulations D3 and D5-2012 [5, 6]. Moreover, the other objective is to find an economical solution along with the economic viability of achieving the nZEB and NZEB when a photovoltaic panels system (PV) as a renewable energy technology (RET) is implemented either to the obtained local cost-optimal or the minimum energy performance solutions. The minimum energy performance solution refers to the solution that has minimum energy consumption.

\section{Methodology}

In this study, to find the local cost-optimal levels, as well as the global cost-optimal level for the implemented heating/cooling energy generation system packages (H/C-EGSs) serving all considered building energy efficiency measure (EEM) combinations, the steps of cost-optimal framework methodology explained in the EU supplementary EPBD recast [3] are followed. Fig. 1 shows in detail the layout of the methodology used to achieve the objectives of this study. In step 1, the reference office building is defined. In step 2, the proposed building EEM are defined and all building EEM combinations are simulated. In step 3, the delivered energies for all combinations are calculated using post-processing of the annual heating, cooling and electrical demands considering the distribution efficiencies, as well as the annual heating 
and cooling average efficiencies. In step 4, the primary energy (PE) consumption is calculated based on a national conversion of primary factors. Additionally in this study, the $\mathrm{CO}_{2}$ equivalent emissions $\left(\mathrm{CO}_{2}\right.$-eq) is evaluated based on $\mathrm{CO}_{2}$ emission factors. The associated costs of delivered energies, of a building's EEM investment, heating and cooling systems, replacement, operation and maintenance (O\&M), and finally, the total incremental life-cycle cost (dLCC) are calculated. In step 5, the cost-optimal solution and the minimum energy performance solution regarding each H/C-EGS, as well as the global cost-optimal solution are determined.

According to the EPBD comparative methodology framework, the life-cycle cost (LCC) calculation is the method used to assess the viability of the building performance. The LCC is the sum of the present value of the investment and discounted operational costs of the building and services systems, including those related to maintenance and replacement, including taxes, over a specified calculation period. In this study, the total incremental life-cycle cost (dLCC) is calculated and presented as a difference cost between each H/C-EGS and a defined reference case which consists of the reference building served by certain H/C- EGS, as given by Eq. (1). The LCC calculation follows a financial cost calculation concerning individual owner perspective [3]. The life-span for office buildings is 20 years as recommended by the EU supplementary EPBD recast [3]. The LCC calculation is illustrated in ANNEX 1 of the supplementary EPBD recast [3].

$$
d L C C(\tau)=L C C-L C C_{r e f}
$$

101

\section{(1)}

It should be mentioned that steps 3-5 are carried out for all considered building EEM combinations and H/C-EGSs. For each H/C-EGS, all considered building EEM combinations drawn in imported PE (or imported $\mathrm{CO}_{2}$-eq emissions) vs lifecycle cost figure create a "cloud" as shown as output in Fig. 1. The imported PE is calculated for the cost-optimal calculations for the imported energies excluding any exported energy following the energy performance calculation method in the Finnish building code D3-2015 [5].

The cost-optimal curves can be derived from the "cloud" of each H/C-EGS separately as well as the two important associated solutions located on the cost-optimal curves, which are the local cost-optimal and minimum energy performance solutions. These two solutions are analyzed with imported $\mathrm{PE}$ and the imported $\mathrm{CO}_{2}$-eq emissions. The imported $\mathrm{CO}_{2}$-eq emissions mean that the released $\mathrm{CO}_{2}$-eq emissions associated with the imported energies. 
The EPBD recast [2] defines a nearly zero-energy building (nZEB) as a building that has a very high energy performance and should be covered to a very significant extent by energy from renewable sources, including energy from renewable sources produced onsite or nearby. Finland has not yet announced an official nZEB definition. Nerveless, it can be assumed that the nZEB requirement is the highest energy efficient class according to the current Finnish regulations building energy certificate [20]. Therefore, for office buildings, the highest energy efficient class is " $\mathrm{A}$ " where the imported PE has to be less than $80 \mathrm{KWh} / \mathrm{m}^{2}$ a. Similarly to the cost-optimal calculation, the nZEB performance is addressed by the imported PE following the energy performance calculation method in [20].

The net zero-energy building (NZEB) is defined as a building with greatly reduced energy needs through efficiency gains such that the balance of energy demand can be supplied with onsite or nearby renewable technologies on a yearly level [21]. However, the NZEB definition and related aspects have to be identified consistently. In this study, the NZEB building boundary is defined to include all H/C-EGSs as the onsite supply option and the necessary space required to install any additional onsite or nearby renewable energy technology (RET). However, the imported fuel has to be taken into account in the NZEB balance. The typical operating energy uses are considered for the balance, including heating, cooling, ventilation, domestic hot water, lighting, HVAC equipment, and appliances. The import/export is the balancing type. Symmetrical nonrenewable PE factors are used for importing and exporting the electricity. Typically, the balance period is a year. The net PE is the metric balance. The NZEB balance is fulfilled when the net PE is equal to or less than zero as shown by Eq. (1).

net $P E=\sum_{i}^{n} P E_{i m p_{i}}-P E_{e x p, E l e}$

where $P E_{i m p}$ is the annual imported primary energy of an energy carrier, $i$ refers to a given imported energy carrier, $n$ is the number of the imported energy carriers crossing the building boundary, and $P E_{\text {exp,Ele }}$ is the annual primary energy associated with the exported electricity.

Reaching the nZEB and NZEB, the photovoltaic panels (PV) are chosen as RET to be implemented in the office building (step 6-Fig. 1). Therefore, the electricity produced via PV can be utilized for the electrical demand to reduce the energy cost of electricity and the surplus electricity can be exported to the grid for compensating the imported energies and to make financial profits. As shown in step 6 in Fig. 1, the PV panels are installed in both the cost-optimal and minimum energy performance solutions for each H/C-EGS. The aim is to investigate the economic viability of achieving the nZEB and NZEB based on both solutions and comparing them. 

different discount rates on the local and global cost-optimal solutions is analyzed.

140

Fig. 1

\section{Computational case study}

\subsection{Reference building description}

145 The office building is the same representative office building identified in [4]. It is a six-story office building with a narrow 146 shape (an approximately $50 \mathrm{~m} \times 22 \mathrm{~m}$ footprint) with the short sides oriented to the east and the west. The room height is $3.6 \mathrm{~m}$. Each floor is $936 \mathrm{~m}^{2}$ and the net heated floor area is $5615 \mathrm{~m}^{2}$. Envelope properties, operation schedule, and set point temperatures of the reference office building are shown in Table 1. More detailed descriptions are presented in [4]. The reference building and all building EEM combinations are simulated using IDA-ICE simulation software [22] using reference year weather data (Vantaa TRY2012) [23] used as well in [4]. Fig. 2 shows a plan for the typical floor and building model in a simulation program. The simulation results indicate that the reference building's demands (excluding any distributed systems' and supply systems' efficiencies.) are $21.7 \mathrm{kWh} / \mathrm{m}^{2} \mathrm{a}$ annual space heating (SPH), $39.3 \mathrm{kWh} / \mathrm{m}^{2} \mathrm{a}$ ventilation heating, $4.6 \mathrm{kWh} / \mathrm{m}^{2}$ a space cooling (SPC), $4.3 \mathrm{kWh} / \mathrm{m}^{2}$ a ventilation cooling, and $6.0 \mathrm{kWh} / \mathrm{m}^{2} \mathrm{a}$ DHW. The electrical demands are $22.3 \mathrm{kWh} / \mathrm{m}^{2}$ a lighting, $22.3 \mathrm{kWh} / \mathrm{m}^{2}$ a appliances, and $13.3 \mathrm{kWh} / \mathrm{m}^{2}$ a HVAC auxiliaries (which includes the fan power, but not the electricity used for direct or indirect heating and cooling).

Fig. 2

Table 1

\subsection{Energy efficiency measures (EEMs) and packages}

In this study, 143 building EEM combinations are proposed to improve the energy performance of the pre-defined reference office building. The proposed building EEMs are categorized into building envelope measures, building service system 
package (BSSP), and heating/cooling energy generation supply packages (H/C-EGS). The building envelope measures include (i) insulation level of external wall, (ii) window type, (iii) infiltration level. The BSSP includes different options of ventilation system and daylight control. Other EEMs such as roof /ground additional insulation, heavy thermal mass, optimal orientation, and solar shading are not considered in this study because they showed low energy-saving potential in [24]. Additionally, the optimal range of the external wall insulation and optimal window parameters and sizes were investigated based on the cost-optimal solutions for office buildings in [25], [26]. The building alternatives of EEMs and their associated costs are obtained from [4], [8], [27], [28] and illustrated in details in Appendix A, including three levels of wall insulation, four different window types, four levels of infiltration, and three options of BSSP. All 144 building EEM combinations including both building envelope measures and BSSP options are integrated into the simulation software to find out the annual heating, cooling and electrical demands.

In this study, sixteen H/C-EGSs (Table 2) investigated with the 144 building EEM combinations yield altogether 2304 cases. The H/C-EGSs are selected to compare between the conventional systems and the other systems based on small-scale CHP and CCHP technologies. Appendix B shows the technical and economic characteristics of all H/C-EGS.

\section{Table 2.}

It should be noticed that the thermal heating and cooling capacities of all heating and cooling systems vary from building combination to another to cover the peak thermal heat demands for each. Also, the capacities of biomass-based CCHP are sized to cover the total peak thermal heating demand required for heating and cooling purposes [29]. The cost of the conventional heating and cooling systems are from [30], [31], [32], [33]. For the GSHP-GC, the borehole lengths required for both heating and free ground cooling purposes of the 144 building combinations are calculated and optimized using EED 3 (Earth Energy Designer) software [34]. The average annual efficiencies of the conventional systems are obtained from the Finnish building codes [5, 6]. The biomass- and fossil fuel-based CHPs' efficiencies, not mentioned in the Finnish building codes are assumed constant and equal to the nominal efficiencies. The costs and performance of the CHPs are from [12], [35], [36], [37] as shown in details in Table B. 5 - Appendix B. Some of the suggested biomass-based CCHP were investigated before, for example, the ORC-AC and SE-AC as biomass CCHP are investigated in [38] and [39]. For the electrical connection fee, the installation cost for $380 \mathrm{~V}$ with electrical current higher than $200 \mathrm{~A}$ is $60 €$ multiplied by the 
peak ampere [30] which vary according to the peak electrical load of the building EEM combinations. All heating and cooling systems have a life span of 20 years. Therefore, there is no replacement for any heating or cooling system. All CHPs are operated to track the thermal demands with ON/OFF operation using the dead band of a water storage system with a capacity of 3.0 cubic meters $[16,11]$. In this study, there is only one value for the annual costs including the subscription costs, as well as operation and maintenance (O\&M) costs.

The reference office building has EEMs of wall 1, win 1, inf 1, BSSP 1 . The reference case consists of the reference building served by DH-VCR as H/C-EGS. The DH-VCR is selected because in the urban area of the Helsinki region, the DH utilized in the building stock has the highest percentage of 85\% [40]. In [4], only the VCR system was investigated as a cooling option for the new office buildings. The DC option has been growing rapidly in the Helsinki region but it is still not a common cooling option [41].

\subsection{Energy performance factors}

The energy performance is commonly defined by the PE consumption, but additionally in this study, is also defined by the $\mathrm{CO}_{2}$-eq emissions as long as the EU target is to reduce the GHG emission by $20 \%$, nevertheless it is not stated in the EPBD recast. The aim is to compare between the PE consumption and the $\mathrm{CO}_{2}$-eq emission as energy performance metrics. The national Finnish conversion PE factors and $\mathrm{CO}_{2}$-eq emission factors are given in Table 3. The national Finnish conversion PE factors are from Finnish building code D5-2012 [6], while the $\mathrm{CO}_{2}$-eq emission factors are from [16, 42].

Table 3.

\subsection{Life-cycle cost parameters}

In this study, the starting year of the cost calculation is 2013. All cost taken from references before 2013 are updated based on building cost indices and inflation rates from [28]. The calculation period is 20 years as recommended for the office building in EU regulation supplementary Directive 2010/31/EU [3]. For the basic calculations, a 3\% real discount rate is used [3]. The sensitivity analysis is carried out with three different real discount rates of $1 \%, 6 \%$, and $10 \%$. All building EEMs have a life span equal to the calculation period, therefore the residual value will equal zero for all EEMs and 
packages. No disposal costs for building elements and EEMs are taken into consideration. Table 4 shows the fuel and energy prices, and their escalation rates obtained from [43]. All energy prices include taxes and transportation costs.

Regarding the exported electricity produced by the multi-generation systems, the current Finnish energy policy for the feedin tariff states that the exported electricity produced via new small scale biomass- and biogas-based CHP has a target price of $83.5 € / \mathrm{MWh}[44]$ where the Energy Market Authority will pay the difference between the target price and the average spot market price every three months. This feed-in tariff scheme is applied for twelve years. In light of that, it is assumed that for all CHP technologies including the fossil fuel-based, the exported electricity price is $83.5 € / \mathrm{MWh}$ without taking into consideration any inflation rate over the calculation period.

Table 4.

\subsection{Implementing PV panels to achieve nZEB and NZEB}

According to the offer provided by local energy distribution companies Fortum Company [30], Helsingin Energia [45] in the Helsinki region, the PV system is installed completely by those companies and they give fees for purchasing the surplus electricity. Based on the offered PV system by [30], the installation price of the whole PV system is $427.6 € / \mathrm{m}^{2}$ (including VAT) with a 20-year guarantee. The annual service fee is $46.70 €$. In this study, the hourly electricity produced by the PV system is calculated by TRNSYS 17.1 software [46] according to its specifications [47] shown in Appendix C using the same reference year's weather data (Vantaa TRY2012) [23]. The orientation of the PV modules is selected to be horizontal to utilize the maximum roof area without losing in-between areas when the PV modules are tilted to avoid the shading effect on each other. Therefore, the maximum collected solar energy can be yielded. The calculated electricity production after the inverter of a one square meter of PV is $119.6 \mathrm{kWh} / \mathrm{a}$. The hourly matching between the electrical demand and the electricity produced via the PV system is carried out using Matlab software.

The exported price of the electricity produced via the PV system varies hourly depending on the spot market price. It is assumed to be equal to the spot market price minus a $0.24 \mathrm{c} / \mathrm{kWh}$ margin fee and a $0.07 \mathrm{c} / \mathrm{kWh}$ online service fee [30]. The hourly and annual average spot market price of 2013 are from Nord pool [48], and shown in Appendix C. The average price 
of $41.16 € / M W h$ is used. The effect of using the average price instead of hourly prices is investigated in Section (4.3.2). It

is assumed that the electricity produced via PV has the same escalation rate as the imported electricity.

\section{$4 \quad$ Results and discussion}

\subsection{Energy demands}

The impact of implementing the separate aforementioned building EEMs to the reference office building is shown in Fig. 3. The reference building has the main EEMs of wall 1, win 1, inf 1, and BSSP 1. The options of EEMs are two wall options (wall 2 and 3), three window types (win 2, 3, and 4), three infiltration levels (inf 2, 3 and 4), and two options of building a service system package (BSSP 2, and 3), see Appendix A, added separately to the reference building. The simulated annual demands are $67 \mathrm{kWh} / \mathrm{m}^{2}$ a for heating, $9 \mathrm{kWh} / \mathrm{m}^{2}$ a for cooling, and $58 \mathrm{kWh} / \mathrm{m}^{2}$ a for electrical demands. The most efficient package among the separate EEM packages is the BSSP including a variable-air volume (VAV) ventilation system with airflows depending on the $\mathrm{CO}_{2}$ levels and daylight control. The energy saving potential are $24 \%$ for the $\mathrm{SPH}$, $80 \%$ for ventilation heating, $55 \%$ for ventilation cooling, $54 \%$ for HVAC auxiliary electrical demands with SFP of $1.8 \mathrm{~kW} /\left(\mathrm{m}^{3} \mathrm{~s}\right)$ (BSSP 1) and $62 \%$ with SFP of $1.4 \mathrm{~kW} /\left(\mathrm{m}^{3} \mathrm{~s}\right)(\mathrm{BSSP} 2)$, while the SPC demand increases by $185 \%$. The explanation of the increase of the SPC is related to withdrawing the heat released by the internal heat and solar gains at night time in the summer (unoccupied time) where the daytime is too long at higher latitudes. Also, the HVAC auxiliary systems and the lighting electrical demand decrease by $62 \%$ and $8 \%$ respectively. Generally speaking, the external wall with low U-value and lower infiltration level than the reference one has a lower heating demand and a higher cooling demand. The window types 2 and 3 reduce the SPC demand by $52 \%$ and increase the SPH demand slightly with respect to the reference building.

Fig. 3.

The total annual heating (including DHW, SPH and ventilation heating), cooling (including SPC and ventilation cooling), electrical (including lighting, appliances, and HVAC auxiliaries) demands of the 144 building EEM combinations including the reference building are shown in Fig. 4. From this figure, the gap on the X-axis (heating demand) between the two groups of building EEM combinations with BSSP 1 and the other group with BSSP 2 is due to the large reduction of the SPH demands when the BSSP 2 and 3 are implemented instead of BSSP 1. All building EEM combinations of the BSSP 1 
have constant electrical demand of $57.9 \mathrm{kWh} / \mathrm{m}^{2} \mathrm{a}$, while those of BSSP 2 and 3 have approximately the electrical demand of $48.8 \mathrm{kWh} / \mathrm{m}^{2} \mathrm{a}$ where it varies between $47.8 \mathrm{kWh} / \mathrm{m}^{2} \mathrm{a}$ and $49.7 \mathrm{kWh} / \mathrm{m}^{2} \mathrm{a}$ in accordance with the fan power of the ventilation system and the daylight control. As shown in Fig. 4, some cases have total heating demand higher than the reference case due to the implementing of window types 2 and 3. It can be concluded that not only for new, but also for retrofitted office buildings that replacing the CAV system with a VAV system is the most efficient EEM with formidable saving potential.

Fig. 4.

\subsection{Cost-optimality calculation}

Depending on the simulation results of all building EEM combinations, the annual imported $\mathrm{PE}$ and $\mathrm{CO}_{2}$-eq emissions are evaluated using post-processing of the annual heating, cooling and electrical demands obtained from the simulation of 144 building cases using the annual average efficiencies of distribution systems and the H/C-EGSs.

Using the financial calculation method, the incremental life-cycle cost is calculated for all cases taking into account the paid costs by the customer including all applicable taxes. The DH-VCR system package serving the reference building is the reference case which has dLCC equal to $0 € / \mathrm{m}^{2}$ as indicated in Section (3.2). The dLCC of all cases are presented with two metrics; imported $\mathrm{PE}$ and imported $\mathrm{CO}_{2}$-eq emissions to evaluate the energy performance of the office building.

\subsubsection{Imported Primary energy (PE) consumption versus incremental life-cycle cost (dLCC)}

Fig. 5 shows the imported PE versus the dLCC of all building EEM combinations served by each H/C-EGS. As shown, for each H/C-EGS, the building EEM combinations are categorized into two groups according to the BSSP options (BSSP 1 and BSSP 2 \&3) presented by the filled and unfilled markers, respectively. The solution space has an imported PE range of $99 \mathrm{kWh} / \mathrm{m}^{2}$ a and $323 \mathrm{kWh} / \mathrm{m}^{2}$ a. The dLCC range is $-83 € / \mathrm{m}^{2}$ and $477 € / \mathrm{m}^{2}$. According to the Finnish building code D32012 [5], the imported PE has to be limited by $170 \mathrm{kWh} / \mathrm{m}^{2}$ a for office buildings. Therefore, the fossil fuel-based CHPs including NG-ICE-VCR, NG-mT-VCR, and D-ICE-VCR with all building combinations of BSSP 1 are not appropriate to be a heating system option due to either high PE factors of NG. Moreover, the biomass-based CHP (ICE-VCR) and CCHP 
291 (ICE-AC) in with some building combinations of BSSP 1 are not appropriate to be a heating system option as well, due in large part to the high amount of imported pellet fuel as a result of low thermal efficiency of the biomass-based ICE.

Fig. 5 shows that the building combinations of BSSP $2 \& 3$ group show not only imported PE savings, but also economic savings over those of the BSSP1 group. This is due to reducing both the investment cost of H/C-EGSs and the energy cost through the building's life span. The cases of building combinations of BSSP $2 \& 3$ with DH-VCR, DH-DC, PB-VCR, and GSHP-GC as conventional H/C-EGSs, PB-AC, ORC-VCR, and SE-VCR have negative dLCC showing the economic savings with respect to the reference cases. Additionally, the cases of BSSP 1 group with PB-VCR and GSHP-GC have also dLCC less than the reference case. The pellet boiler technology, which is a mature product with the advantage of running on an abundance of biomass fuels, requires relatively low investment and annual costs. The pellet fuel price and its escalation rate are the lowest among all energy carriers. The GSHP-GC is a low-operating-cost, environmentally friendly H/C-EGS.

Regarding the multi-generation systems shown in Fig. 5, it can be noticed that biomass-based CHP technologies with high $\mathrm{P} / \mathrm{H}$ ratio (such as IFGT and ICE) cannot compete with the conventional systems due to the following reasons. The first one is the high investment cost relating to high heating and electrical capacities as well (Table 5.B - Appendix B). The second reason is that high $\mathrm{P} / \mathrm{H}$ ratio, which means low thermal efficiency yields to high operational cost since the $\mathrm{CHP}$ operational strategy is the thermal tracking. On the contrary, the biomass-based CHP technologies with low P/H ratio (such as SE and ORC) can compete with the conventional systems. Also, for the same building EEM combination, it is found that the imported PE increases for the PB and biomass-based CHPs when the VCR is replaced by AC as a cooling system. From the imported PE point of view, the increase of the imported PE varies from one building EEM combination to another, depending on the thermal performance of the PB and biomass-based CHPs. The PB-AC has the imported PE increase by a range of $3 \mathrm{kWh} / \mathrm{m}^{2}$ a and $7 \mathrm{kWh} / \mathrm{m}^{2}$ a while the ICE-AC, for example, undergoes an increase of the imported PE in range of $6 \mathrm{kWh} / \mathrm{m}^{2} \mathrm{a}$ and $14 \mathrm{kWh} / \mathrm{m}^{2} \mathrm{a}$. From the net PE consumption point of view, the net PE consumption records increase for the PB and reduction for biomass-based CHPs due to the associated electricity production. The net PE consumption of the PBAC increases in range of $3 \mathrm{kWh} / \mathrm{m}^{2} \mathrm{a}$ and $7 \mathrm{kWh} / \mathrm{m}^{2} \mathrm{a}$, while the IFGT-AC, for example, undergoes a reduction of the net PE consumption in the range of $4 \mathrm{kWh} / \mathrm{m}^{2} \mathrm{a}$ and $10 \mathrm{kWh} / \mathrm{m}^{2} \mathrm{a}$. Therefore, it can be concluded that the biomass-based CCHP does not have an environmental advantage with respect to the imported PE according to the current Finnish energy calculation regulations in [5] and [20], while it will be feasible with respect to the net PE consumption. From an economic point of view, the dLCC increases significantly as a result of increase in the investment cost of both biomass-based CHP 
and the $\mathrm{AC}$ as well as the purchased fuel. The same conclusion of the lack of economic viability of a small scale biomassbased CCHP was reached by [29] and [49].

Fig. 5

Table 5 shows the cost-optimal and minimum energy performance solutions regarding the imported PE for all H/C-EGSs. The reference case has imported PE of $162.4 \mathrm{kWh} / \mathrm{m}^{2} \mathrm{a}$. The global cost-optimal solution belonging to the GSHP-GC has dLCC of $-83 € / \mathrm{m}^{2}$ and an imported PE of $107 \mathrm{kWh} / \mathrm{m}^{2}$ a, with an overall savings of $34 \%$ with respect to the reference case. Its building EEM combinations are wall 1, win 1, and inf 1 and BSSP 2. The GSHP-GC is a low-operating-cost, environmentally friendly H/C-EGS with high thermal performance (COP coefficient of performance). The PB-VCR has an imported PE of $117 \mathrm{kWh} / \mathrm{m}^{2} \mathrm{a}$ and $\mathrm{dLCC}$ of $-82 € / \mathrm{m}^{2}$ due to the abovementioned features of PB technology and low pellet fuels price and escalation rate. The H/C-EGSs based on the district heating; the DH-VCR and DH-DC, are the second and fifth cost-optimal solutions which have dLCC of $-73 € / \mathrm{m}^{2}$ and $-36 € / \mathrm{m}^{2}$, respectively. The VCR has an advantage over the DC because it has lower annual costs where the O\&M cost of the VCR is less than the sum of the annual subscription and the O\&M costs of the DC system (Table B. 1 and Table B. 4 - Appendix B).

Regarding the multi-generation systems, the ORC-VCR and SE-VCR have the lowest dLCC among all CHP and CCHP systems of $-55 € / \mathrm{m}^{2}$ and $-49 € / \mathrm{m}^{2}$ corresponding to an imported PE of $113 \mathrm{kWh} / \mathrm{m}^{2} \mathrm{a}$ and $112 \mathrm{kWh} / \mathrm{m}^{2} \mathrm{a}$, respectively. Table 5 shows that, the IFGT-AC has the highest exported PE of $34 \mathrm{kWh} / \mathrm{m}^{2}$ a. Therefore, it has the minimum net PE of 92 $\mathrm{kWh} / \mathrm{m}^{2} \mathrm{a}$ but high additional $\mathrm{dLCC}$ due to high thermal capacity as well as the operational cost corresponding to high imported fuel. The fossil fuel-based CHP systems record the highest imported PE as well as relatively high dLCC.

The difference between the dLCC of the global cost-optimal solution of GSHP-GC and that of GH-DC (which has maximum negative incremental life-cycle cost of $\left.-36 € / \mathrm{m}^{2}\right)$ is $47 € / \mathrm{m}^{2}$. Comparing this value with the global cost-optimal $\left(1889 € / \mathrm{m}^{2}\right)$ given by [4], even though the difference between the life span used in this study (20 years) and that used in [4] (40 years), it is found that it yields less than $2.5 \%$. Therefore, due to inputs data uncertainty, each of these system combinations GSHP-GC, PB-VCR, DH-VCR, ORC-VCR, SE-VCR, and DH-DC could be the global cost-optimal solution. 
Table 5.

As shown in Table 5, the local cost-optimal solutions for all biomass-based CHPs, and NG-ICE-VCR have building EEM combinations of wall 2, win 2, inf 4, and BSSP 2 as the cost effective EEMs from both heating and cooling demands. Once the AC and DC cooling systems are implemented, there is no need to invest more in the infiltration level due to dependency on the lowest energy carriers' costs. Therefore, the DH-DC and all CCHPs have building EEM combinations of wall 2, win 2, inf 1, and BSSP 2. However, for the GSHP-GC, PB-VCR, and DH-VCR which have the lowest dLCC and the highest heating efficiency and/or COP, there is no need to invest more in the building EEMs, only implementing the most efficient EEM (i.e., BSSP 2) in the reference building. Due to high energy prices of the fossil fuel supplied to the fossil fuel-based CHPs, the local cost-optimal solutions have high levels of the building EEM combinations of wall 2, win 4, inf 4, and BSSP 3 except the NG-ICE-VCR with relatively low P/H. The minimum energy performance solutions for all H/C-EGSs have the highest EEM levels of wall 3, win 4, inf 4, and BSSP 3.

Fig. 6 shows the breakdown of the cost-optimal solutions of all H/C-EGSs with respect to the reference case costs. It can be noticed that all local cost-optimal solutions bring with them additional investment costs due to the implementation of the EEMs. Because all local cost optimal solutions have either BSSP 2 or BSSP3, which consist of VAV system and daylight control, all cost-optimal solutions have energy cost savings by way of reduced electrical demands. The highest electrical demand cost saving is recorded by biomass- and fossil fuel-based CHPs having high $\mathrm{P} / \mathrm{H}$ ratios and all biomass-based CCHPs. The GSHP-GC is the only system that has investment and operational cost savings covering the cooling demand with respect to the VCR of the reference case as a result of free ground cooling, which mainly needs a pumping system. The DC has high investment and operational cost over the VCR of the reference case by $43 € / \mathrm{m}^{2}$. The high investment and operational cost increase of the AC for PB-AC and all biomass-based CCHPs over the VCR of reference case is not only due to the difference of the cooling system itself, but also includes the investment and operational cost difference of the heating system supplying the AC system. other factors are not reflected in the comparative framework methodology and/or excluded in this study. For example, the heating/cooling system package's reliability, social acceptance, local emission, additional space required depending on the footprint, fuel procurement and storage, etc. have a strong influence on the decision making. 
Fig. 7 shows the imported $\mathrm{CO}_{2}$-eq emissions versus the dLCC for all building EEM combinations for each H/C-EGS. The imported $\mathrm{CO}_{2}$-eq emissions mean the released $\mathrm{CO}_{2}$-eq emissions associated with the imported energies, whereas the exported $\mathrm{CO}_{2}$-eq emissions mean the displaced $\mathrm{CO}_{2}$-eq emissions in the grid associated with the exported energies from renewable energy sources, using the symmetric $\mathrm{CO}_{2}$-eq emission factors. The imported $\mathrm{CO}_{2}$-eq emissions are in range of $13.1 \mathrm{~kg}_{\mathrm{CO} 2} / \mathrm{m}^{2} \mathrm{a}$ and $76.2 \mathrm{~kg}_{\mathrm{CO} 2} / \mathrm{m}^{2}$ a. It can be noted that for biomass-based CHP and CCHP systems, the difference between the imported $\mathrm{CO}_{2}$-eq emissions between the building EEM combinations of BSSP 1 and BSSP $2 \& 3$ is very small. The building EEM combinations with BSSP $2 \& 3$ have always imported $\mathrm{CO}_{2}$-eq emissions lower than ones with BSSP 1 . The net $\mathrm{CO}_{2}$-eq emissions can be defined as the difference between the imported and exported $\mathrm{CO}_{2}$-eq emissions. From the net $\mathrm{CO}_{2}$-eq emissions point of view, the building EEM combinations with BSSP $2 \& 3$ have lower net $\mathrm{CO}_{2}$-eq emissions than ones with BSSP 1, except the ORC. The reason is mainly related to the very low $\mathrm{CO}_{2}$-eq emission factor of pellet fuel compared to other energy carriers. As concluded in [16] for net $\mathrm{CO}_{2}$-eq emissions, as long as the biomass-based CHP systems are operated under a thermal tracking strategy, the possibility of producing electricity which can be utilized by the electrical demand or exported to the grid, is decreased with highly efficient thermal demands, leading to an increase in the net $\mathrm{CO}_{2}$-eq emissions. Replacing the VCR by AC with the PB and all biomass-based CHP achieves reduction in the imported $\mathrm{CO}_{2}$-eq emissions and net $\mathrm{CO}_{2}$-eq emissions as well. Significant reductions of the imported $\mathrm{CO}_{2}$-eq emissions of $17 \%, 16 \%, 15 \%$, and $14 \%$ are obtained when the AC is implemented instead of VCR as a cooling system with SE, ORC, IFGT, and ICE, respectively. Once the displaced $\mathrm{CO}_{2}$-eq emissions in the grid associated with the exported electricity is taken into account, the net $\mathrm{CO}_{2}$-eq emissions reduces by $41 \%, 39 \%, 23 \%$, and $20 \%$ with IFCT, ICE, ORC, and SE, respectively, when the AC is implemented instead of the VCR. one illustrated with the imported PE results. As shown in Table 6, the global cost-optimal solution has imported $\mathrm{CO}_{2}$-eq 
emissions of $16.9 \mathrm{~kg}_{\mathrm{CO} 2} / \mathrm{m}^{2} \mathrm{a}$, with a savings of $50 \%$ with respect to the reference case which has imported $\mathrm{CO}_{2}$-eq

emissions of $33.8 \mathrm{~kg}_{\mathrm{CO} 2} / \mathrm{m}^{2}$ a. The imported $\mathrm{CO}_{2}$-eq emissions savings are higher than the imported PE savings of the local cost-optimal solutions for each H/C-EGS with respect to the reference case except the NG-mT-VCR and the D-ICE-VCR. The reason is primarily related to the PE factors and $\mathrm{CO}_{2}$-eq emission factors. It can be concluded that, under Finnish conditions, the imported $\mathrm{CO}_{2}$-eq emissions as an energy performance metric is a straightforward way to achieve the EU target of reducing the GHG emissions by $20 \%$. However, the argument of evaluating the energy performance using either the PE consumption or the $\mathrm{CO}_{2}$-eq emissions primarily depends on the national factors where the results obtained by this study cannot be generalized.

The minimum imported $\mathrm{CO}_{2}$-eq emission solutions of all biomass-based systems except the ORC-AC do not have the most efficient EEMs as shown in the minimum imported PE solutions. This is primarily related to a very low pellet fuel $\mathrm{CO}_{2}$-eq emission factor with respect to other energy carriers. However, the difference between the minimum imported $\mathrm{CO}_{2}$-eq emission solutions and the cases with the most efficient EEMs is less than $0.02 \mathrm{~kg}_{\mathrm{CO} 2} / \mathrm{m}^{2} \mathrm{a}$.

Table 6.

\section{3 nZEB and NZEB calculations}

\subsubsection{Implementing $P V$ to reach $n Z E B$ and NZEB levels}

416 In the context of the aforementioned nZEB and NZEB definitions, PV as a RET is implemented to reach nZEB and NZEB. As shown in Fig. 8, the PV system in a $200 \mathrm{~m}^{2}$ module step is installed "onsite" reaching $1000 \mathrm{~m}^{2}$, which is approximately equal to the roof area of the office building while over $1000 \mathrm{~m}^{2}$; it has to be installed "nearby." The local cost-optimal solutions for all H/C-EGSs are extended by installing a PV area equal to the maximum PV area determined to achieve the NZEB balance between the imported and exported PE as given in Table 5. Meanwhile, the minimum energy performance (min imported PE) solutions are extended only for the GSHP-GC with imported PE of $75 \mathrm{kWh} / \mathrm{m}^{2} \mathrm{a}$ and $\mathrm{dLCC}$ of $-30 € / \mathrm{m}^{2}$, where the proposed nZEB imported PE limit is reached by installing the PV system onsite (i.e., PV area $\leq 1000 \mathrm{~m}^{2}$ ). It can be noticed that the PV area $\leq 1000 \mathrm{~m}^{2}$ has a small increase in the dLCC. The reason is primarily related to the high correlation between the PV electricity production and the electrical demand. The percentage of the onsite utilized electricity varies between $65 \%$ and $72 \%$ depending on the H/C-EGS. However, small addition LCC is observed as the difference 
between both the investment cost of a PV system and the exported electricity and the annual cost saving of the imported electricity. Over a $1000 \mathrm{~m}^{2} \mathrm{PV}$ area, where the PV area has to be installed nearby, the percentage of the onsite utilized electricity produced by the PV system is decreased and the dLCC increases rapidly due to the low feed-in tariff of the exported electricity. The dLCC of the extended local cost-optimal solutions by PV system are less than those of the extended minimum energy performance solutions as presented by the GSHP-GC. Therefore, the NZEB balance is fulfilled and presented by the local cost-optimal solutions of each H/C-EGS.

The NZEB balance is fulfilled when the maximum PV area is implemented for the local cost-optimal solution each H/CEGS given in Table 5. The additional cost required for the cost-optimal solutions of the NZEB varies from H/C-EGS to

Fig. 8

ICE-VCR, respectively. Using the PV systems, the NZEB has always dLCC higher than the reference case. The extension of the global cost optimal (GSHP-GC) to reach NZEB balance has dLCC of $39 € / \mathrm{m}^{2}$. However, the extended local cost optimal solutions of PB-VCR, DH-VCR, ORC-VCR, and SE-VCR all have dLCC less than $64 € / \mathrm{m}^{2}$. The minimum imported/exported PE belongs to the global cost optimal solution (GSHP-GC) extended by $2946 \mathrm{~m}^{2}$ of $63 \mathrm{kWh} / \mathrm{m}^{2} \mathrm{a}$ followed by the local cost optimal solutions of ORC-VCR and SE-VCR with $64 \mathrm{kWh} / \mathrm{m}^{2}$ a. However, as concluded in [19], the low imported PE does not necessarily indicate the high-energy-matching situation, especially when different imported energies (i.e., fuels) are imported beside the electricity and thermal heat.

\subsubsection{The effect of using the hourly spot price as a feed-in tariff instead of using the annual average value}

In the base calculation, the prices of exported electricity produced by the PV system are calculated using the annual average value of the spot market price for 2013. Repeating the nZEB and NZEB cost calculation using the hourly spot price as a feed-in tariff instead of the annual average value for 2013; it is found that the difference is negligible. The maximum dLCC variation when the hourly spot price used with the global cost optimal solution (i.e., GSHP-GC extended by $2946 \mathrm{~m}^{2}$ PV area as an example) is equal to $1.6 € / \mathrm{m}^{2}$ more the dLCC when the average annual value is used. 


\subsection{Sensitivity analysis}

453 The sensitivity analysis is carried out to show the effect of different real discount rates on the local cost-optimal solutions 454 for all H/C-EGSs. The basic real discount rate used as aforementioned is $3 \%$. Other three real different discount rates are selected: $1 \%, 6 \%$, and 10\%. Fig. 9 shows the imported PE and dLCC of the local cost-optimal solutions where the H/CEGSs are in ascending order based on their dLCC of the base calculation of $3 \%$ of the real discount rate. The dLCC is calculated relative to its reference case cost with the same real discount rate, therefore the costs of reference cases with all real discount rates are drawn on zero value. The change of the imported PE for the same H/C-EGSs with different real discount rates means a change in its cost-optimal solutions' building EEM combinations. It can be concluded that, the GSHP-GC is a global cost optimal solution with low real discount rates of $1 \%$ and $3 \%$. The DH-VCR and PB-VCR become the global cost-optimal solutions, with $6 \%$ and $10 \%$ real discount rates, respectively. The DH-VCR and DH-DC become more economic than the ORC-VCR and SE-VCR with high real discount rates of 6\% and 10\%. All biomass-based CCHPs are the most expensive system packages with high real discount rates of $6 \%$ and $10 \%$. Natural gas and diesel oil have high energy costs and high escalation rates. Therefore the discounted annual costs of the fossil fuel are decreased significantly compared to other energies when the real discount factors increases. Additionally, increasing the imported PE of $6 \%$ and $10 \%$ real discount rates cases yields that the dLCCs are close together for all studied real discount rates.

Fig. 9

\section{Conclusion}

This study aims to find the local cost-optimal solutions for the minimum energy performance building for a representative

472 office building located in Helsinki, Finland. The Energy Performance of Building Directive (EBPD) comparative framework methodology is used. Four building energy efficiency measures (EEMs); external wall insulation, window type, infiltration level, and building service system package (BSSP) options consisting of the ventilation system and daylight control are included to address the building EEM combinations. Sixteen heating/cooling energy generation packages (H/CEGS) consisting of small-scale multi-generation systems along with conventional heating and cooling systems are investigated. These multi-generation systems are biomass- and fossil fuel-based combined heat and power (CHP), as well 
as biomass-based combined cooling, heating, and power (CCHP). The energy performance is presented by two metrics; imported primary energy (PE) and imported $\mathrm{CO}_{2}$ equivalent $\left(\mathrm{CO}_{2}\right.$-eq) emissions. The lifecycle cost is presented by the incremental life-cycle cost (dLCC) over the reference case integrating the reference building built in compliance with the prevailing Finnish building codes (D3 and D5-2012) served by the district heating and vapor compression refrigeration (DH-VCR) system package. As a further step, the photovoltaic panels (PV) as a renewable energy technology (RET) are implemented, aiming to reach nearly zero-energy building (nZEB) and net zero-energy building (NZEB). The nZEB imported PE is proposed to be limited by the Finnish energy class "A" of $80 \mathrm{kWh} / \mathrm{m}^{2}$ a for office buildings. The nZEB and NZEB costs for each H/C-EGS, extended based on the cost-optimal and the minimum energy performance solutions are compared. The following findings are obtained:

- The solution space has an imported PE in the range of $99 \mathrm{kWh} / \mathrm{m}^{2} \mathrm{a}$ and $323 \mathrm{kWh} / \mathrm{m}^{2} \mathrm{a}$, and imported $\mathrm{CO}_{2}$-eq in the range of $13.1 \mathrm{~kg} \mathrm{CO}_{2} / \mathrm{m}^{2}$ a and $76.2 \mathrm{~kg}_{\mathrm{CO} 2} / \mathrm{m}^{2}$ a. The $\mathrm{dLCC}$ range is $477 € / \mathrm{m}^{2}$ and $-83 € / \mathrm{m}^{2}$. The reference case has an imported PE of $162.4 \mathrm{kWh} / \mathrm{m}^{2} \mathrm{a}$, and imported $\mathrm{CO}_{2}$-eq emissions of $33.8 \mathrm{~kg} \mathrm{CO}_{2} / \mathrm{m}^{2} \mathrm{a}$. All fossil fuel-based CHPs and the biomass-based CCHP with high power-to-heat $(\mathrm{P} / \mathrm{H})$ ratio and low overall efficiency (Indirect fire gas turbine (IFGT) and internal combustion engine (ICE)) with all building EEM combinations of BSSP options consisting of a constant air volume (CAV) ventilation system without daylight control have imported PE higher than the Finnish building code limit value of $170 \mathrm{kWh} / \mathrm{m}^{2} \mathrm{a}$.

- The fossil fuel-based CHPs recorded the worst economic and environmental solutions due to high PE factors and high energy prices with high escalation rates as well.

- The global cost-optimal solution relates to a GSHP-GC with dLCC of $-83 € / \mathrm{m}^{2}$, an imported PE of $107 \mathrm{kWh} / \mathrm{m}^{2} \mathrm{a}(34$ $\%$ lower than the reference case), and $\mathrm{CO}_{2}$-eq emissions of $16.9 \mathrm{~kg}_{\mathrm{CO}_{2}} / \mathrm{m}^{2} \mathrm{a}(50 \%$ lower than the reference case).

- Since the investigated CHPs operate under a thermal tracking strategy, the Organic Rankine Cycle (ORC) and the Stirling Engine (SE) technologies, the ORC-VCR and SE-VCR with high overall efficiency and low P/H ratios, resulting low investment and low operational costs, have the lowest dLCC among all CHP and CCHP systems in the range of $-55 € / \mathrm{m}^{2}$ and $-49 € / \mathrm{m}^{2,}$ and imported PE of $113 \mathrm{kWh} / \mathrm{m}^{2} \mathrm{a}$ and $112 \mathrm{kWh} / \mathrm{m}^{2} \mathrm{a}$, respectively.

- The biomass-based CCHPs do not have economic or environmental benefits over the biomass-based CHPs due to significant increase of the investment cost of biomass-based CHP and the absorption chiller (AC), as well as the purchased pellets fuel. 
- Regarding the proposed nZEB, the local cost-optimal solutions extended by onsite PV area $\left(\leq 1000 \mathrm{~m}^{2}\right.$, equal to the office roof area) cannot fulfill the proposed limit of $80 \mathrm{kWh} / \mathrm{m}^{2} \mathrm{a}$, while the extended minimum energy performance solutions can fulfill the nZEB limit only for the GSHP-GC with imported PE of $75 \mathrm{kWh} / \mathrm{m}^{2} \mathrm{a}$ and dLCC of $-30 € / \mathrm{m}^{2}$.

- The NZEB solutions extended based on the cost-optimal solutions for all H/C-EGSs have lower dLCC than that of the extended based minimum energy performance solutions.

- The NZEB achieved by extending the global cost optimal (GSHP-GC) has a dLCC of $39 € / \mathrm{m}^{2}$. However, the extended local cost optimal solutions of PB-VCR, DH-VCR, ORC-VCR, and SE-VCR have dLCC less than $64 € / \mathrm{m}^{2}$.

As shown, since the EEMs and H/C-EGSs are applicable to be implemented in either new or existing buildings, the results of this study can help the designers throughout the design process of nearly and net ZEB for new construction of, and the retrofitting of existing office buildings. Additionally, the results will be also useful to the policy makers since the legislation of Finnish nearly ZEB will be set in the coming years.

\section{Acknowledgment}

The authors would like to acknowledge the Finnish Academy (grant numbers 272780 (2013-2015) and 140966 (20102013)), Aalto University SAGA project, as well as the Tekes RYM-Indoor Environment project (grant number 704/11) for partly funding this research. The authors also would like to acknowledge our colleague, $\mathrm{PhD}$ Juha Jokisalo who provided us the representative office building. Juha Jokisalo was a team member in preparing the Finnish report of minimum energy performance requirements for calculating the cost-optimal levels in Finland.

\section{Appendix A Energy efficiency measures and their costs}

The proposed energy efficiency measures (EEM) included the computational case study; external wall insulation levels, window types, infiltration levels, and building service system package (BSSP) (ventilation system and daylight control) are listed in Table A. 1, Table A. 2, Table A. 3, Table A. 4, respectively.

Table A. 1

Table A. 2

Table A. 3

Table A. 4 
Table B. 1

534

Table B. 2

536

Table B. 3

538

Table B. 4

Table B. 5

Finnish spot market price for 2013 and specifications of the PV modules are shown in Fig. C. 1, and Table C. 1, respectively

Table C. 1

\section{References}

[1] Directive 2012/27/EU of the European Parliament and of the Council of 25 October 2012 on the energy efficiency. | Official Journal of the European Union; 2012. 14/11/2012.

[2] EPBD recast, Directive 2010/31/EU of the European Parliament and of the Council of 19 May 2010 on the energy performance of buildings (recast). Official Journal of the European Union; 2010. 18/06/2010.

[3] Guidelines accompanying commission delegated regulation (EU) No 244/2012 of 16 January 2012 supplementing Directive 2010/31/EU of the European Parliament and of the Council on the energy performance of buildings by establishing a comparative methodology framework for calculating cost-optimal levels of minimum energy performance requirements for buildings and building elements, Official Journal of the European Union; 2012

[4] Ministry of the Environment, Finland, Energiatehokkuutta koskevien vähimmäisvaatimusten kustannusoptimaalisten tasojen laskenta-SUOMI. Minimum energy performance requirements for calculating cost-optimal levels-Finland. (in Finnish) http://ec.europa.eu/energy/efficiency/buildings/implementation_en.htm

[5] D3 Finland Code of building Regulation. Energy management in buildings, regulations and guidelines. Helsinki: Ministry of Environment; 2012.

[6] D5 Finland Code of building Regulation. Calculation of power and energy needs for the heating of buildings, guidelines. Helsinki: Ministry of Environment; 2012.

[7] Mohamed Hamdy, Ala Hasan, Kai Sirén. Applying a multi-objective optimization approach for Design of low-emission cost-effective dwellings, Build. Environ. 46 (2011) 109-123. doi:10.1016/j.buildenv.2010.07.006

[8] Mohamed Hamdy, Ala Hasan, Kai Sirén. A multi-stage optimization method for cost-optimal and nearly-zero-energy building solutions in line with the EPBD-recast 2010, Energy Build. 56 (2013) 189-203. doi:10.1016/j.enbuild.2012.08.023 
[9] B. Güçyeter, H.M. Günaydın, Optimization of an envelope retrofit strategy for an existing office building, Energy Build. 55 (2012) 647-659. doi:10.1016/j.enbuild.2012.09.031

[10] N. Ganiç, A.Z. Yılmaz, Adaptation of the cost optimal level calculation method of Directive 2010/31/EU considering the influence of Turkish national factors, Appl. Energy. 123 (2014) 94-107. doi:10.1016/j.apenergy.2014.02.045

[11] Robert Beith, Small and Micro Combined Heat and Power (CHP) Systems: Advanced Design, Performance, Materials And Applications, Woodhead Publishing Limited, 2011. Part I: Overview of small and micro combined heat and power (CHP) systems, Pages 3-16. doi:10.1533/9780857092755.1.3

[12] S.R. Wood, P.N. Rowley, A techno-economic analysis of small-scale, biomass-fuelled combined heat and power for community housing, Biomass and Bioenergy. 35 (2011) 3849-3858. doi:10.1016/j.biombioe.2011.04.040

[13] Y. Huang, D.R. McIlveen-Wright, S. Rezvani, M.J. Huang, Y.D. Wang, A.P. Roskilly, et al., Comparative technoeconomic analysis of biomass fuelled combined heat and power for commercial buildings, Appl. Energy. 112 (2013) 518525. doi:10.1016/j.apenergy.2013.03.078

[14] Y. Huang, Y.D. Wang, S. Rezvani, D.R. Mcllveen-Wright, M. Anderson, N.J. Hewitt, Biomass fuelled trigeneration system in selected buildings, Energy Convers. Manag. 52 (2011) 2448-2454. doi:10.1016/j.enconman.2010.12.053

[15] D. Maraver, A. Sin, F. Sebastián, J. Royo, Environmental assessment of CCHP (combined cooling heating and power) systems based on biomass combustion in comparison to conventional generation, Energy. 57 (2013) 17-23. doi:10.1016/j.energy.2013.02.014

[16] A. Mohamed, A. Hasan, K. Sirén, Fulfillment of net-zero energy building (NZEB) with four metrics in a single family house with different heating alternatives, Appl. Energy. 114 (2014) 385-399. doi:10.1016/j.apenergy.2013.09.065

[17] S. Thiers, B. Peuportier, Energy and environmental assessment of two high energy performance residential buildings, Build. Environ. 51 (2012) 276-284. doi:10.1016/j.buildenv.2011.11.018

[18] S. Cao, A. Mohamed, A. Hasan, K. Sirén, Energy matching analysis of on-site micro-cogeneration for a single-family house with thermal and electrical tracking strategies, Energy Build. 68, Part A (2014) 351-363.

doi:10.1016/j.enbuild.2013.09.037

[19] A. Mohamed, S. Cao, A. Hasan, K. Sirén, Selection of micro-cogeneration for Net Zero Energy Buildings (NZEB)

using weighted energy matching index, Energy Build. 80 (2014) 490-503. doi:10.1016/j.enbuild.2014.05.055

[20] Ministry of the Environment Regulation, the building energy certificate, Ympäristöministeriön asetus, rakennuksen energiatodistuksesta, February 2013. Available at: http://www.finlex.fi/fi/laki/alkup/2013/20130176 (in Finnish).

[21] Torcellini P, Pless S, Deru M. Zero energy buildings: a critical look at the definition. USA: National Renewable

Energy Laboratory (NREL); June 2006. http://www.nrel.gov/docs/fy06osti/39833.pdf

[22] IDA-ICE, IDA Indoor Climate and Energy, http://www.equa.se/ice/intro.html

[23]T. Kalamees, K. Jylhä, H. Tietäväinen, J. Jokisalo, S. Ilomets, R. Hyvönen, et al., Development of weighting factors for climate variables for selecting the energy reference year according to the EN ISO 15927-4 standard, Energy Build. 47

(2012) 53-60. doi:10.1016/j.enbuild.2011.11.031

[24] K. Flodberg, A. Blomsterberg, M.-C. Dubois, Low-energy office buildings using existing technology: simulations with low internal heat gains, Int. J. Energy Environ. Eng. 3 (2012) 19. doi:10.1186/2251-6832-3-19

[25] M. Thalfeldt, E. Pikas, J. Kurnitski, H. Voll, Facade design principles for nearly zero energy buildings in a cold climate, Energy Build. 67 (2013) 309-321. doi:10.1016/j.enbuild.2013.08.027

[26] E. Pikas, M. Thalfeldt, J. Kurnitski, Cost optimal and nearly zero energy building solutions for office buildings, Energy Build. (2014). doi:10.1016/j.enbuild.2014.01.039

[27] Isover Saint-Gobain, http://www.isover.fi/ , (Accessed 30.07.2013)

[28] Statistics Finland, Building cost indices, http://www.stat.fi/til/rki/index_en.html

[29] Y. Huang, Y.D. Wang, S. Rezvani, D.R. McIlveen-Wright, M. Anderson, N.J. Hewitt, Biomass fuelled trigeneration system in selected buildings, Energy Convers. Manag. 52 (2011) 2448-2454. doi:10.1016/j.enconman.2010.12.053

[30] Fortum Company, Fortum.fi (Accessed 30.07.2013).

[31] Janfire Company. www.janfire.fi. Direct contact.

[32] Y. Haahtela, J. Kiiras, Talonrakennuksen kustannustieto 2013 (Building Construction Cost Data 2013), Haahtela-

kehitys, Helsinki $\square$ ISBN: 978-952-5403-21-3 (sid.), (In Finnish)

[33] Carrier Company, Finland, www.carrier.fi. Direct contact.

[34] Earth Energy Designer (EED 3) software, http://www.egshpa.com/eed-earth-energy-designer/

[35] Technology data for energy plants. Danish Energy Agency and Energinet.dk, May 2012. (Available at http://www.energinet.dk/SiteCollectionDocuments/Danske\%20dokumenter/Forskning/Technology data_for_energy_plants $. \mathrm{pdf})$

[36] Maciej Lukawski, Design and Optimization of Standardized Organic Rankine Cycle Power Plant for European Conditions. RES-the School for Renewable Energy Science. Akureyri, February 2009. http://hdl.handle.net/1946/7113

[37] Commercial and Industrial CHP Technology Cost and Performance Data Analysis for EIA, June 2010 
http://www.meede.org/wp-content/uploads/Commercial-and-Industrial-CHP-Technology-Cost-and-Performance-DataAnalysis-for-EIA June-2010.pdf (Accessed: Feb 2013)

[38] D. Maraver, A. Sin, J. Royo, F. Sebastián, Assessment of CCHP systems based on biomass combustion for small-scale applications through a review of the technology and analysis of energy efficiency parameters, Appl. Energy. 102 (2013) 1303-1313. doi:10.1016/j.apenergy.2012.07.012

[39] D. Maraver, A. Sin, F. Sebastián, J. Royo, Environmental assessment of CCHP (combined cooling heating and power) systems based on biomass combustion in comparison to conventional generation, Energy. 57 (2013) 17-23.

doi:10.1016/j.energy.2013.02.014

[40] City of Helsinki, http://www.hel.fi/hel2/ymk/julkaisut/oppaat/esitteet/teemakatsaus_engl.pdf .

[41] Marko RIIPINEN, Niko WIRGENTIUS, DHC in Helsinki - The Ultimate Heating and Cooling Solution for a Large Urban Area, 2010, available at http://www.worldenergy.org/documents/congresspapers/355.pdf

[42] M. Kantola, A. Saari, Renewable vs. traditional energy management solutions - A Finnish hospital facility case, Renew. Energy. 57 (2013) 539-545. doi:10.1016/j.renene.2013.02.023

[43] Statistics Finland, Energy, Energy prices. 〈https://www.stat.fi/til/ehi/index en.html>

[44] Energy Authority, Renewable energy, http://www.energiavirasto.fi/en/web/energy-authority/renewable-energy (Accessed 30.07.2013).

[45] Helsingin Energia, https://www.helen.fi/ (Accessed 30.07.2013).

[46] Solar Energy Laboratory. Univ. of Wisconsin-Madison. TRNSYS 17 - a TRaNsientSYstem. Simulation program; 2010. http://sel.me.wisc.edu/trnsys/index.html

[47] Naps solar systems http://www.napssystems.com/ (Accessed: June 2013).

[48] Nord pool spot webpage, http://www.nordpoolspot.com/. (Accessed 30.3.2014).

[49] Y. Huang, Y.D. Wang, S. Rezvani, D.R. McIlveen-Wright, M. Anderson, J. Mondol, et al., A techno-economic assessment of biomass fuelled trigeneration system integrated with organic Rankine cycle, Appl. Therm. Eng. 53 (2013) 325-331. doi:10.1016/j.applthermaleng.2012.03.041 
Fig. 1 Schematic diagram for the layout of the methodology.

Fig. 2 Typical floor plan and the 3D model in IDA ICE of the simulated reference office building.

Fig. 3. Annual energy demands of the reference building (consists of wall 1, win 1, inf 1, and BSSP 1) and the effect of changing one EEM on the reference building (indicated by EEM changed from the reference case).

Fig. 4. Heating, Cooling, and electrical demands of the 144 building EEM combinations.

Fig. 5 Incremental life-cycle cost (dLCC) versus imported primary energy (PE) for all building EEM combinations integrated with H/C-EGSs. Filled and unfilled markers refer to BSSP 1 and BSSP $2 \& 3$ combinations, respectively. The dashed lines link visually between the two groups for each H/C-EGS. For interpretation of each marker's color, the reader is referred to the web version of the article.

Fig. 6 Breakdown of the local cost-optimal solutions of all H/C-EGSs with respect to the reference case costs. For interpretation of each marker's color, the reader is referred to the web version of the article.

Fig. 7 Incremental lifecycle costs versus imported $\mathrm{CO}_{2}$-eq emissions for all building EEM combinations integrated with H/C-EGSs. Filled and unfilled markers refer to BSSP 1 and BSSP 2\&3, respectively. The dashed lines link visually between the two groups of each H/C-EGS. For interpretation of each marker's color, the reader is referred to the web version of the article.

Fig. 8 The incremental life-cycle cost of implementing a PV system in $200 \mathrm{~m}^{2}$ modules versus the imported PE for the local cost-optimal solutions of each H/C-EGS. The GSHP-GC has two extensions based on local cost-optimal (filled marker) and minimum energy performance solutions (unfilled marker). The IFGT-AC and ICE-AC are out of the dLCC range. The EEM combinations and maximum PV area achieving the NZEB are given in Table 5. For interpretation of each marker's color, the reader is referred to the web version of the article.

Fig. 9 The cost-optimal solutions versus the imported PE consumption for each heating/cooling system package at different discount rates. The H/C-EGSs are in ascending order according to the cost-optimal solutions obtained from base calculation with a $3 \%$ discount rate .For interpretation of each marker's color, the reader is referred to the web version of the article.

Fig. C. 1 Finnish spot market price for 2013; hourly distribution (left), histogram (right) 
1. Defining the reference building

2. Defining the building EEMs and simulating all possible building EEM combinations. (using IDA-ICE software)

3. Post-processing the annual demands of building EEM combinations using the average annual efficiencies to calculate the delivered energies for the heating/cooling energy generation system package (H/C-EGSP)

(using Matlab software)

4. Calculating the life cycle cost, primary energy consumption and $\mathrm{CO}_{2}$ equivalent emissions for all possible combinations and $\mathrm{H} / \mathrm{C}$-EGSPs

(using Matlab software)

5. Getting the cost-optimal solution, the minimum energy performance solution, regarding each H/C-EGSP. Sorting the cost optimal solutions for all H/C-EGSPs in ascending order

(using Matlab software)

6. Implementing the PV system on both cost-optimal and minimum energy performance solutions to determine on which economical solution the attainment of nZEB and NZEB will be based

(using Matlab software)
Hourly and annual heating, cooling, and electrical demands

Hourly and annual heating, cooling, and electrical demands.
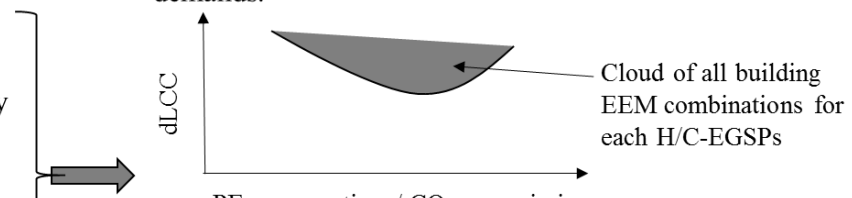

$\mathrm{PE}$ consumption / $\mathrm{CO} 2$-eq emissions

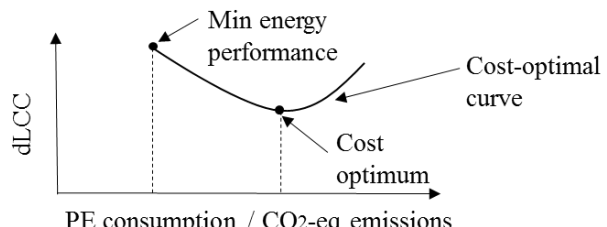

PE consumption / CO2-eq emissions

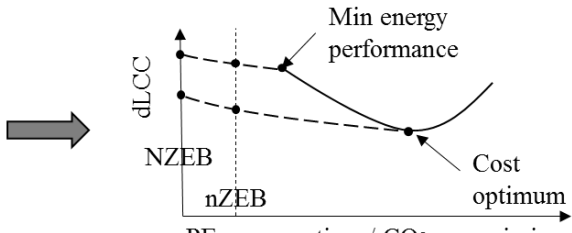

$\mathrm{PE}$ consumption / CO2-eq emissions

Fig. 1 Schematic diagram for the layout of the methodology.
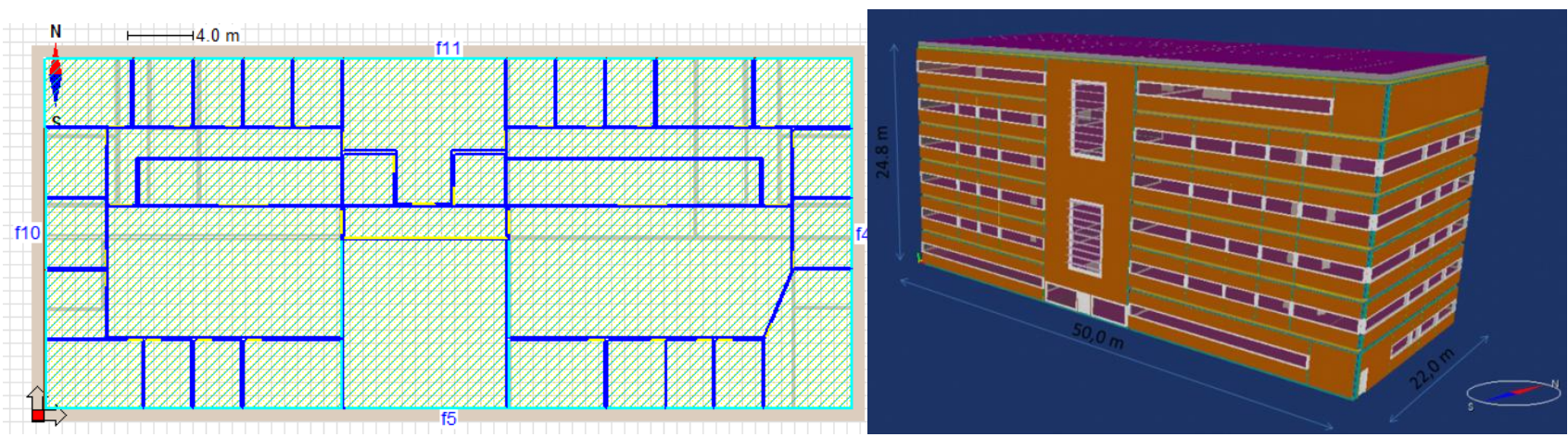

Fig. 2 Typical floor plan and the 3D model in IDA ICE of the simulated reference office building. 


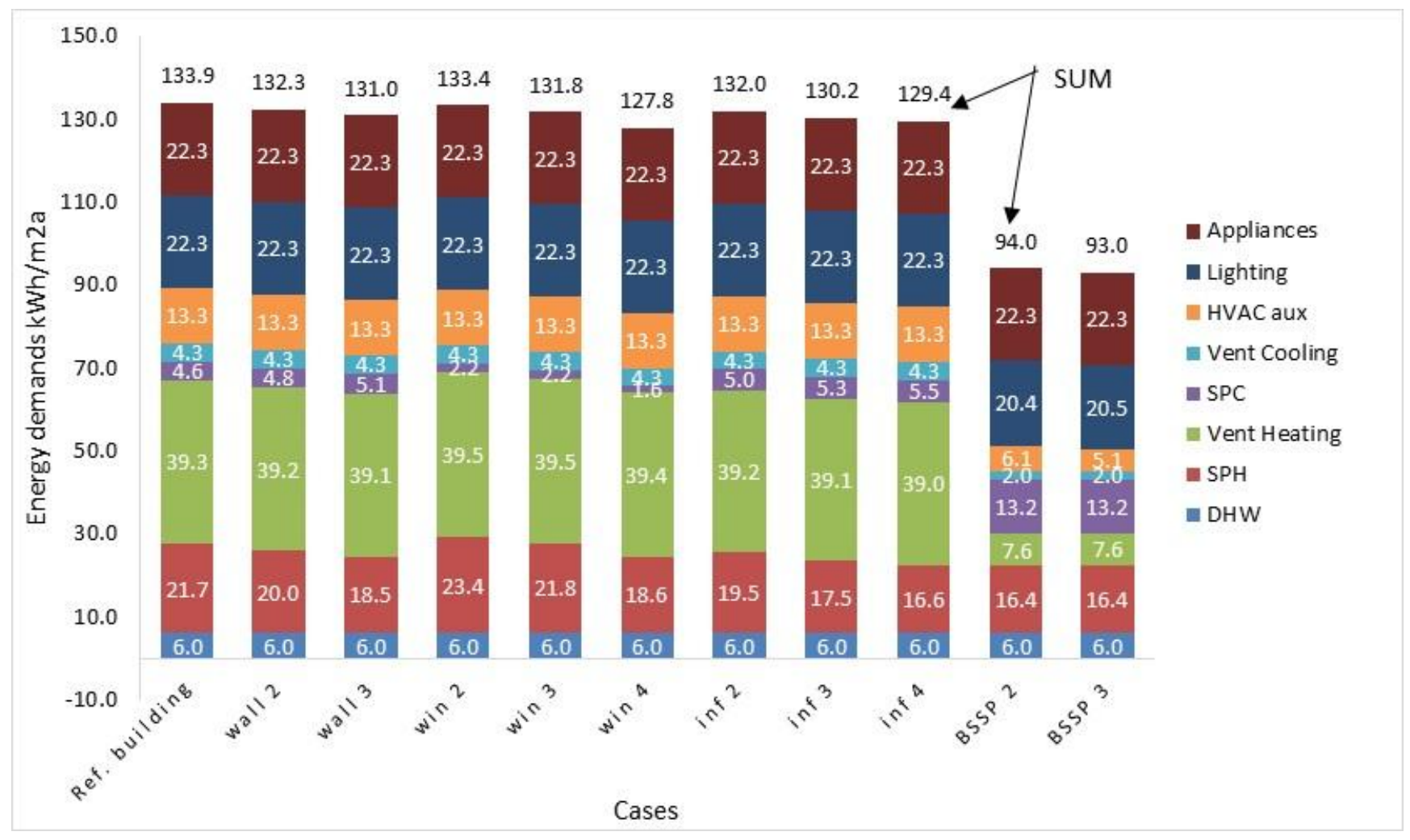

Fig. 3. Annual energy demands of the reference building (consists of wall 1, win 1, inf 1, and BSSP 1) and the effect of changing one EEM on the reference building (indicated by EEM changed from the reference case).

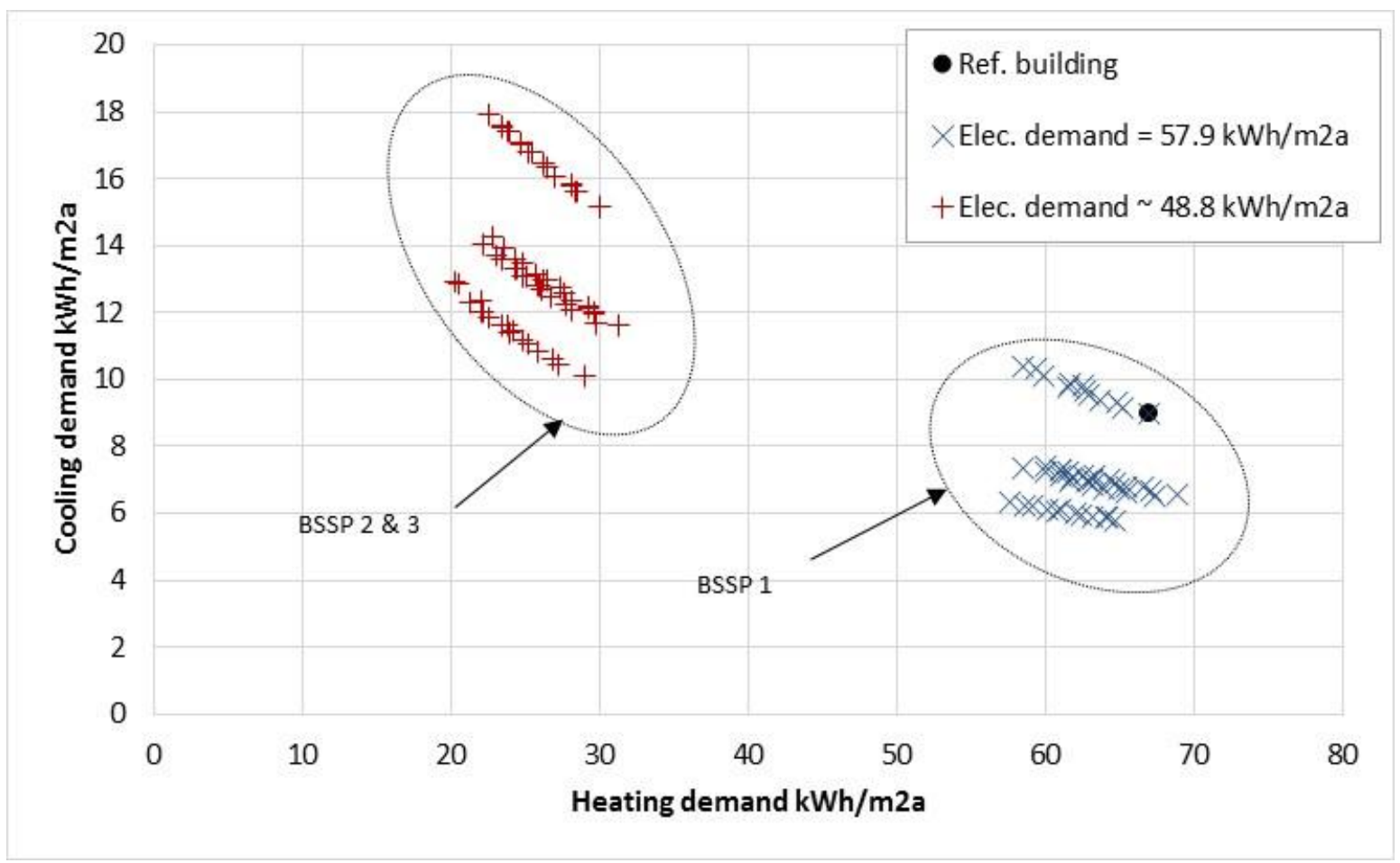

Fig. 4. Heating, Cooling, and electrical demands of the 144 building EEM combinations. 


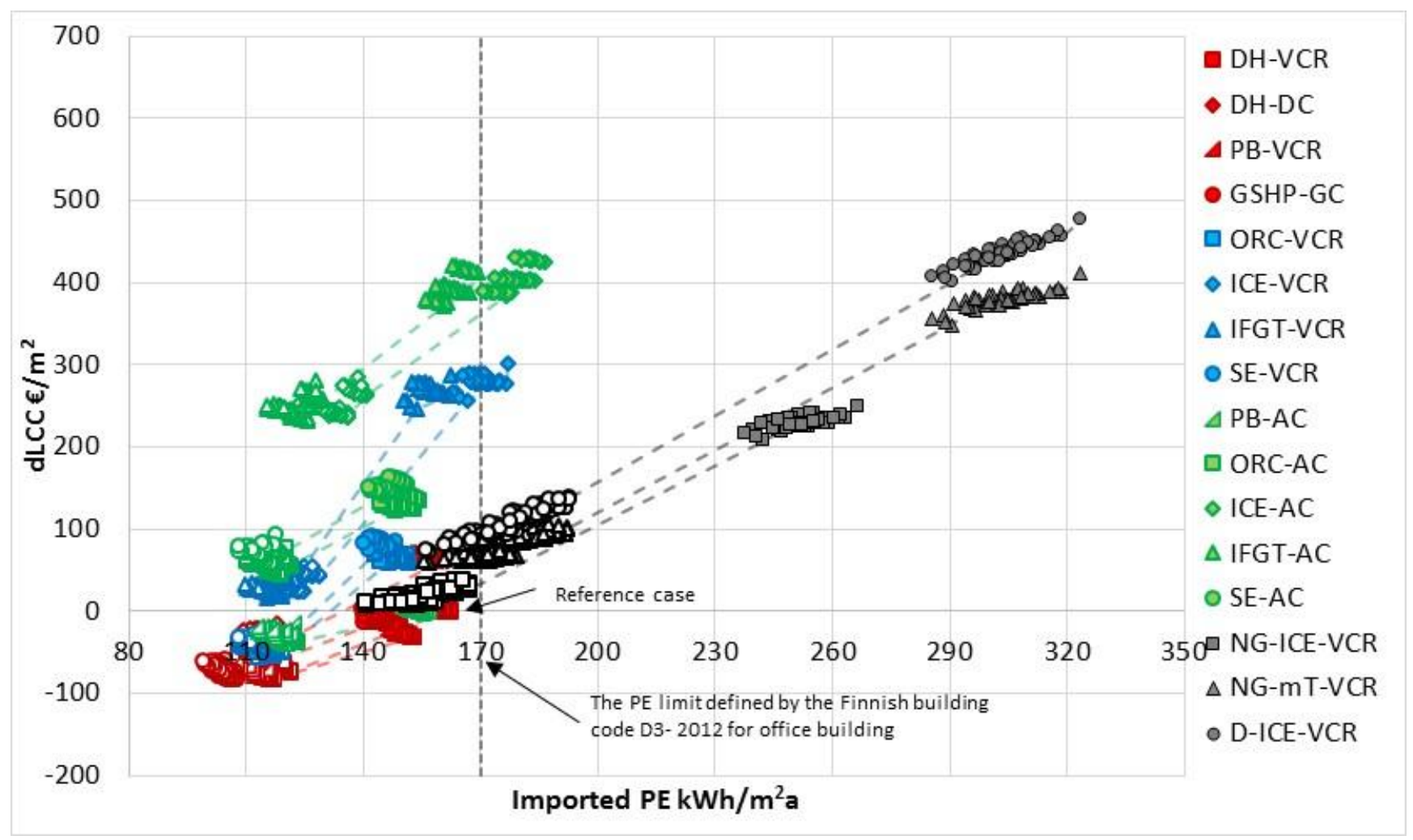

Fig. 5 Incremental life-cycle cost (dLCC) versus imported primary energy (PE) for all building EEM combinations integrated with H/C-EGSs. Filled and unfilled markers refer to BSSP 1 and BSSP $2 \& 3$ combinations, respectively. The dashed lines link visually between the two groups for each H/C-EGS. For interpretation of each marker's color, the reader is referred to the web version of the article. 


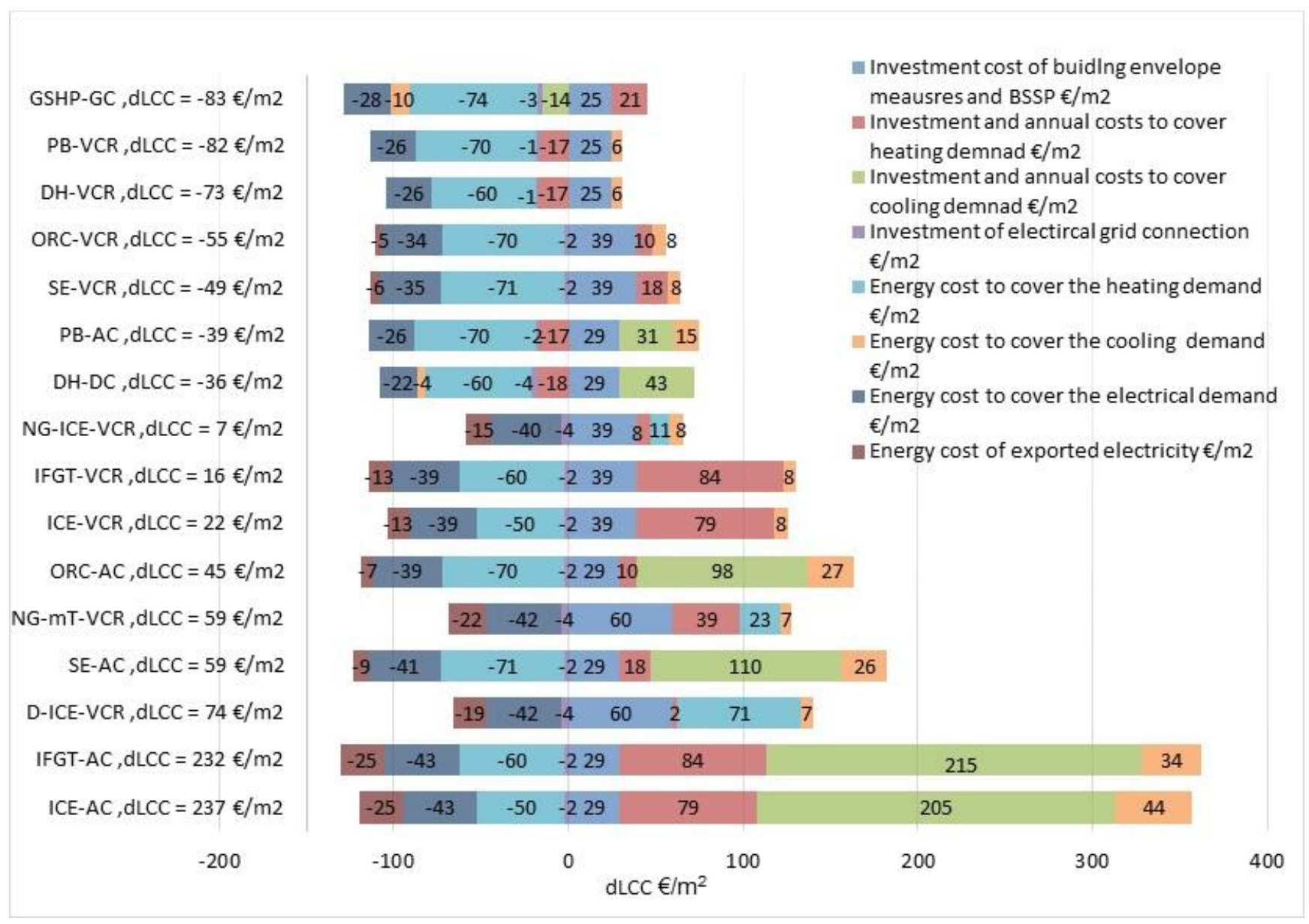

Fig. 6 Breakdown of the local cost-optimal solutions of all H/C-EGSs with respect to the reference case costs. For interpretation of each marker's color, the reader is referred to the web version of the article. 


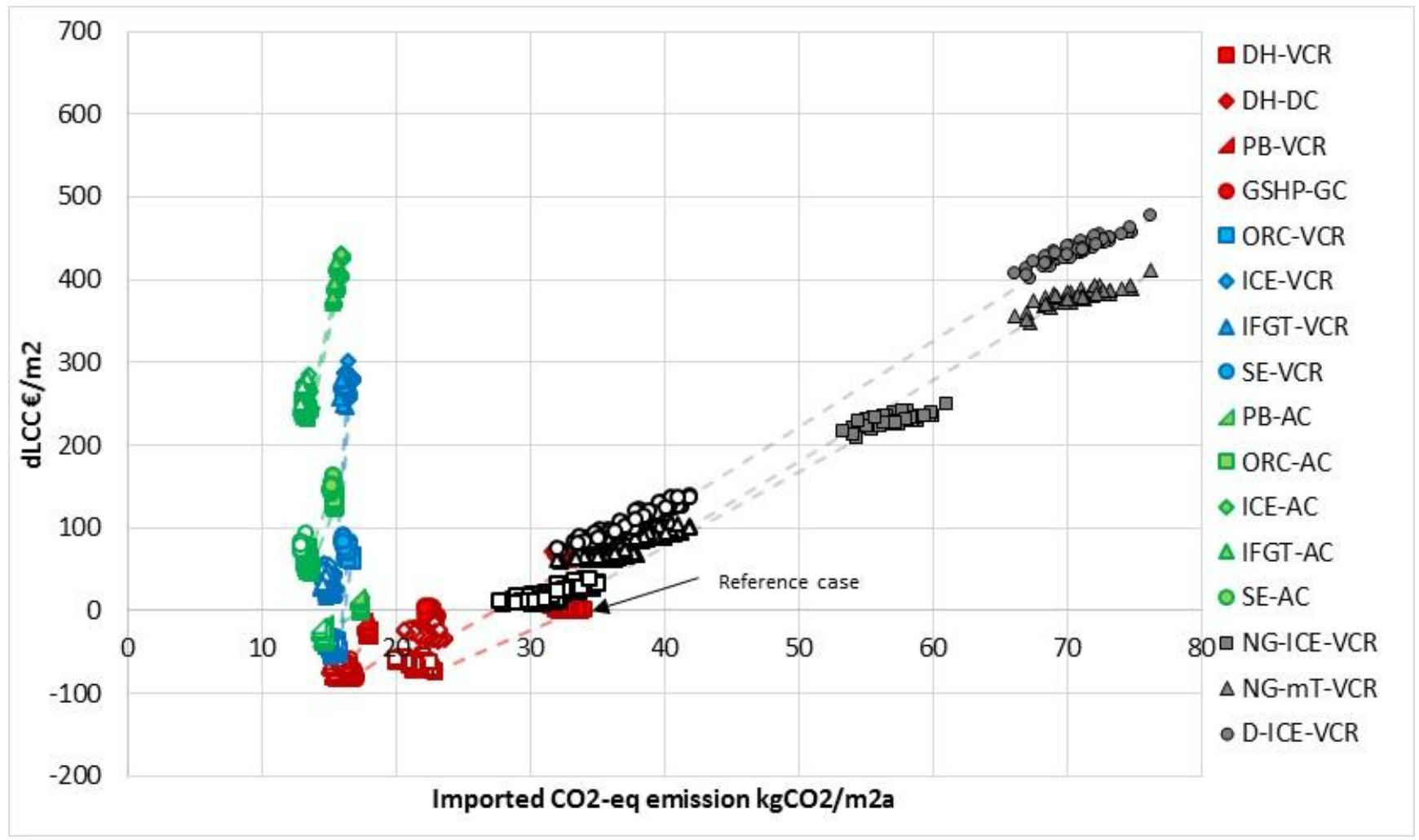

Fig. 7 Incremental lifecycle costs versus imported $\mathrm{CO}_{2}$-eq emissions for all building EEM combinations integrated with H/C-EGSs. Filled and unfilled markers refer to BSSP 1 and BSSP 2\&3, respectively. The dashed lines link visually between the two groups of each H/C-EGS. For interpretation of each marker's color, the reader is referred to the web version of the article. 


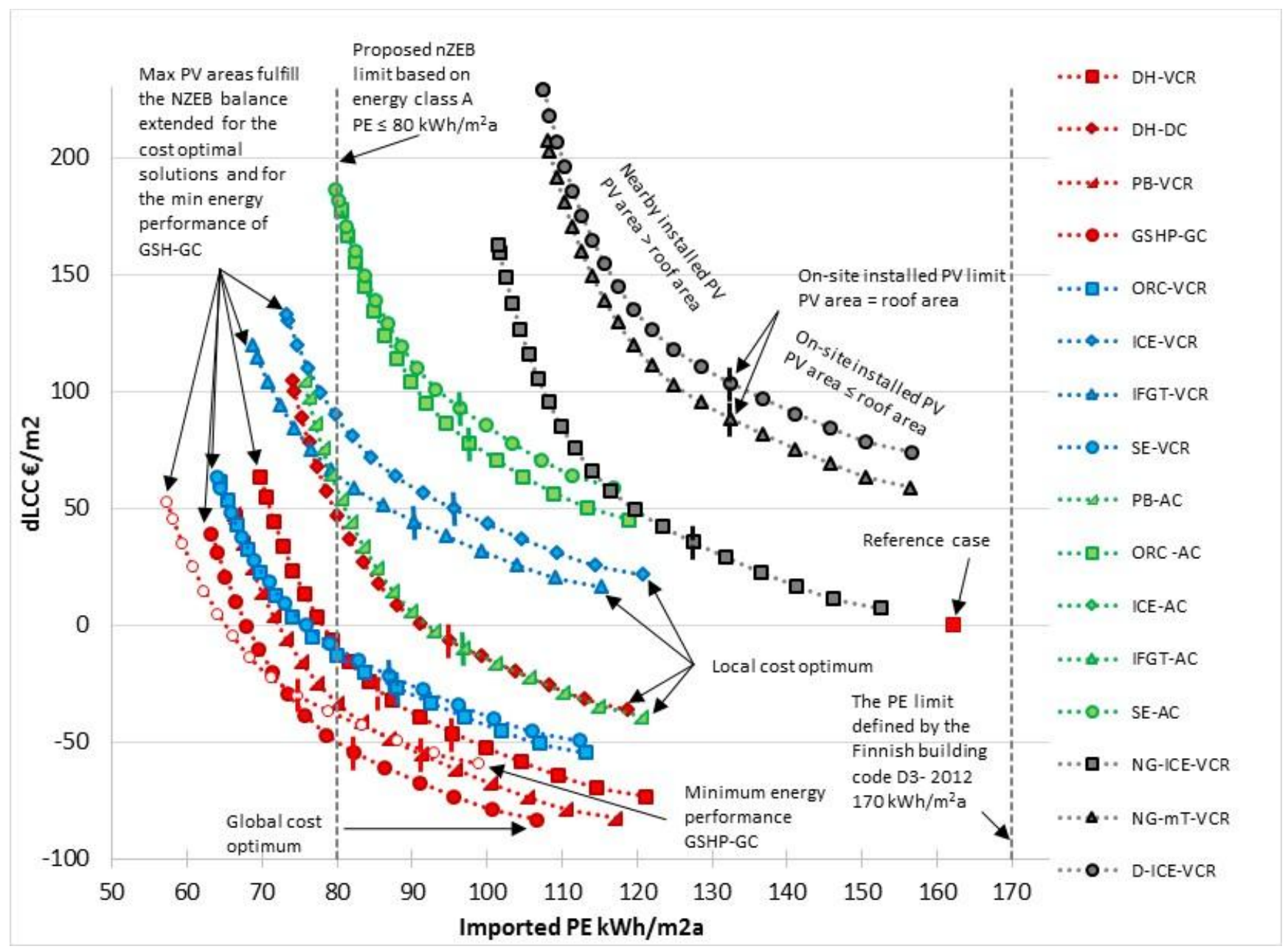

Fig. 8 The incremental life-cycle cost of implementing a PV system in $200 \mathrm{~m}^{2}$ modules versus the imported PE for the local cost-optimal solutions of each H/C-EGS. The GSHP-GC has two extensions based on local cost-optimal (filled marker) and minimum energy performance solutions (unfilled marker). The IFGT-AC and ICE-AC are out of the dLCC range. The EEM combinations and maximum PV area achieving the NZEB are given in Table 5. For interpretation of each marker's color, the reader is referred to the web version of the article. 


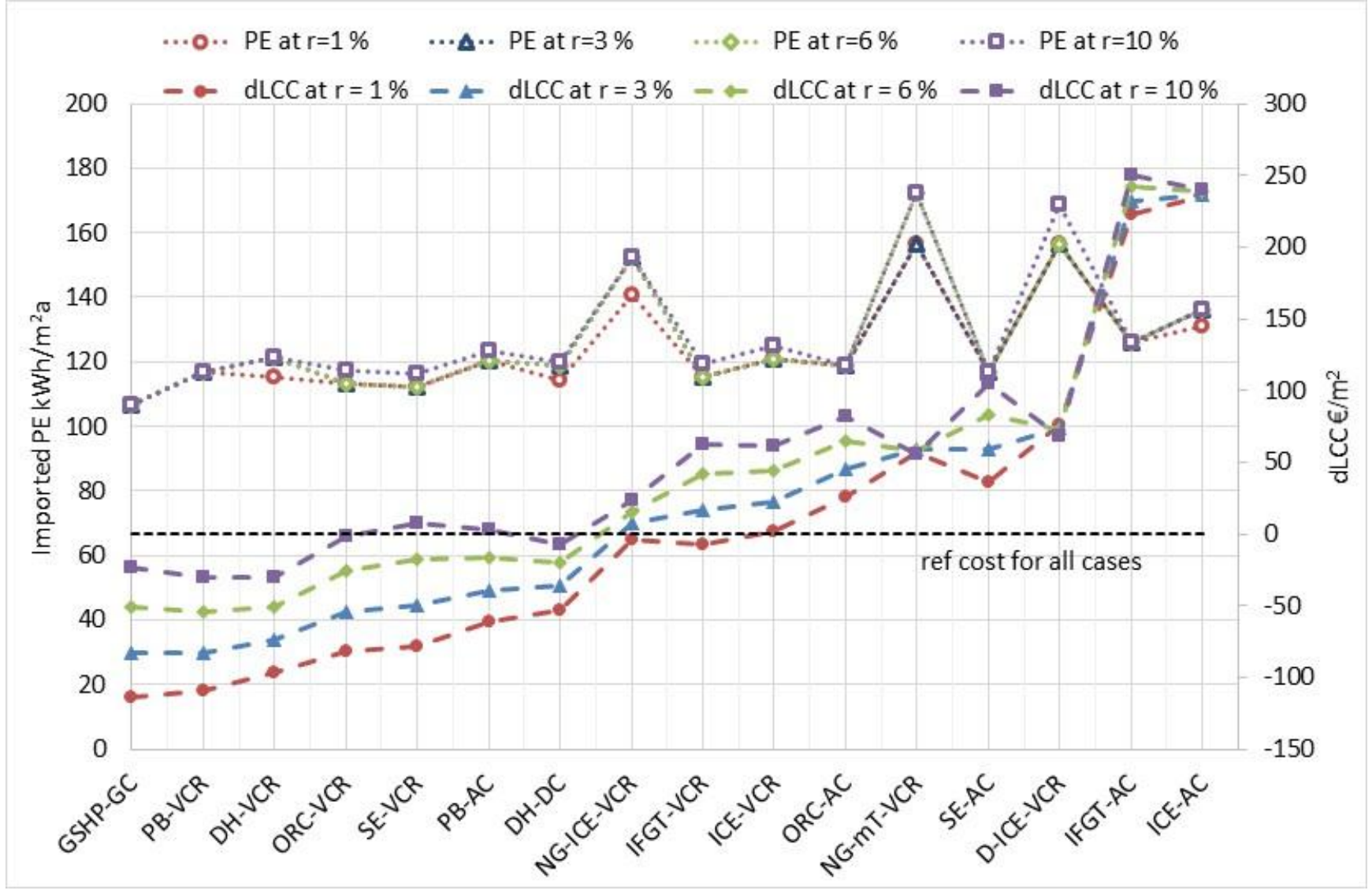

Fig. 9 The cost-optimal solutions versus the imported PE consumption for each heating/cooling system package at different discount rates. The H/C-EGSs are in ascending order according to the cost-optimal solutions obtained from base calculation with a 3\% discount rate .For interpretation of each marker's color, the reader is referred to the web version of the article.
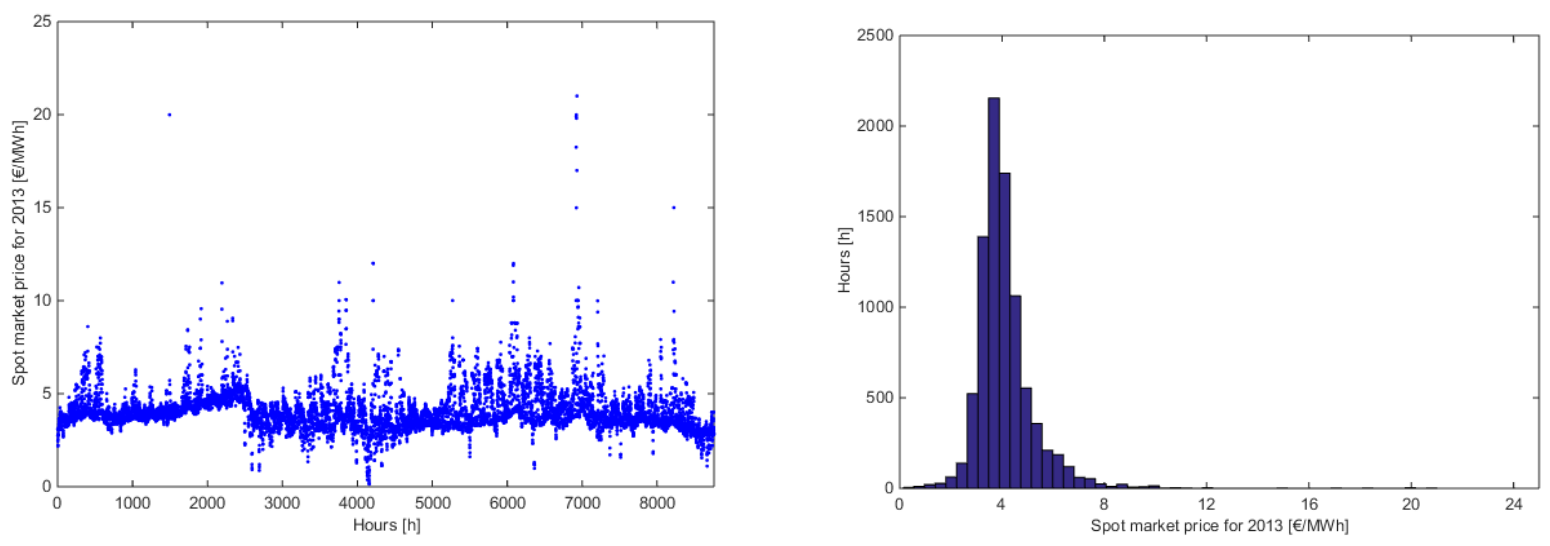

Fig. C. 1 Finnish spot market price for 2013; hourly distribution (left), histogram (right) 
Table 1 Envelope properties, operation schedules, and set points of the reference office building [4].

\begin{tabular}{|l|l|}
\hline Property description & Value \\
\hline U-value of walls & $0.17 \mathrm{~W} / \mathrm{m}^{2} \mathrm{~K}$ \\
\hline U-value of roof & $0.09 \mathrm{~W} / \mathrm{m}^{2} \mathrm{~K}$ \\
\hline U-value of ground floor & $0.16 \mathrm{~W} / \mathrm{m}^{2} \mathrm{~K}$ \\
\hline U-value of windows & $1.0 \mathrm{~W} / \mathrm{m}^{2} \mathrm{~K}$ \\
\hline SHGC of Glazing factor & $0.68(-)$ \\
\hline Overall window to wall ratio & $27.2 \%$ \\
\hline Infiltration rate (air change per hour) & $0.94(50 \mathrm{~Pa}) 1 / \mathrm{h}$ \\
\hline Occupancy schedule & Weekdays $07: 00-18: 00^{\mathrm{a}}$ \\
\hline Lighting schedule and control & Weekdays 07:00 - 18:00 ${ }^{\mathrm{a}}$ \\
\hline Appliances schedule and control & Weekdays $07: 00-18: 00^{\mathrm{a}}$ \\
\hline Ventilation schedules and control & Weekdays $06: 00-19: 00^{\mathrm{a}}$ \\
& at other times $0.151 / \mathrm{sm}^{2}$ \\
\hline Heating set point temperature & $21^{\circ} \mathrm{C}$ \\
\hline Cooling set point temperature & $25^{\circ} \mathrm{C}$ \\
\hline Heating system & Always On \\
\hline Cooling system & Always On \\
\hline
\end{tabular}

${ }^{a}$ All detailed profiles depend on the zones utilization, for example, offices, meeting rooms, etc. [4].

Table 2. Heating/cooling energy generation system packages (H/C-EGSs).

\begin{tabular}{|l|l|}
\hline Heating/cooling energy generation system package (H/C-EGS) description & Abbreviation \\
\hline District heating and vapor compression refrigeration system & DH-VCR \\
\hline District heating and district cooling systems & DH-DC \\
\hline Pellet boiler and vapor compression refrigeration system & PB-VCR \\
\hline Ground source heat pump and free ground cooling & GSHP-GC \\
\hline Biomass-based organic Rankine cycle and vapor compression refrigeration system & ORC-VCR \\
\hline $\begin{array}{l}\text { Biomass-based internal combustion engine with gasifier and vapor compression } \\
\text { refrigeration system }\end{array}$ & ICE-VCR \\
\hline Biomass-based indirect fire gas turbine and vapor compression refrigeration system & IFGT-VCR \\
\hline $\begin{array}{l}\text { Biomass-based updraft gasifier with stirling engine and vapor compression refrigeration } \\
\text { system }\end{array}$ & SE-VCR \\
\hline Pellet boiler and absorption chiller system & PB-AC \\
\hline Biomass-based organic Rankine cycle and absorption chiller system & ORC-AC \\
\hline Biomass-based internal combustion engine with gasifier and absorption chiller system & ICE-AC \\
\hline Biomass-based indirect fire gas turbine and absorption chiller system & IFGT-AC \\
\hline Biomass-based updraft gasifier with stirling engine and absorption chiller system & SE-AC \\
\hline Natural gas-based internal combustion engine and vapor compression refrigeration system & NG-ICE-VCR \\
\hline Natural gas-based micro-turbine and vapor compression refrigeration system & NG-mT-VCR \\
\hline Diesel-based internal combustion engine and vapor compression refrigeration system & D-ICE-VCR \\
\hline
\end{tabular}

Table 3. Energy carriers' primary energy and $\mathrm{CO}_{2}$-equivalent emission factors.

\begin{tabular}{|l|l|l|l|l|l|l|l|}
\hline Energy carrier & Electricity & DH & DC & Pellets & NG & Diesel oil & Ref \\
\hline $\begin{array}{l}\text { Primary energy factor } \\
\mathrm{kWh}_{\mathrm{pe}} / \mathrm{kWh}\end{array}$ & 1.7 & 0.7 & 0.4 & 0.5 & 1 & 1 & {$[6]$} \\
\hline
\end{tabular}




\begin{tabular}{|l|l|l|l|l|l|l|l|}
\hline $\begin{array}{l}\mathrm{CO}_{2 \text {-eq }} \text { emission factor } \\
\mathrm{kg}_{\mathrm{CO} 2} / \mathrm{kWh}\end{array}$ & 0.269 & 0.216 & 0.12 & 0.01 & $0.267^{\mathrm{a}}$ & $0.267^{\mathrm{a}}$ & {$[16,42]$} \\
\hline
\end{tabular}

${ }^{a} \mathrm{NG}$ and Diesel oil $\mathrm{CO}_{2}$ emission factors are based on [16], otherwise [42].

Table 4. Energy and fuel prices, and their escalation rates

\begin{tabular}{|l|l|l|}
\hline Energy carrier & ${\text { Price }(\mathrm{c} / \mathrm{kWh})^{\mathrm{a}}}^{\mathrm{a}}$ & ${\text { escalation rate }(\%)^{\mathrm{b}}}^{\mathrm{a}}$ \\
\hline Electricity & 15.480 & $2.74 \%$ \\
\hline $\mathrm{DH}$ & 7.967 & $1.78 \%$ \\
\hline DC $^{\mathrm{c}}$ & 2.600 & $1.78 \%$ \\
\hline Pellets & 5.600 & $1.54 \%$ \\
\hline NG & 6.597 & $6.50 \%$ \\
\hline Diesel & 11.290 & $4.42 \%$ \\
\hline
\end{tabular}

${ }^{a}$ All prices are annual average prices based on 2013 and obtained from [43].

${ }^{\mathrm{b}}$ The escalation rate is calculated based on the energy price evolution for last 10 years.

${ }^{\mathrm{c}}$ Since the district cooling historical data are not available, it is assumed that it has same escalation rate as DH.

Table 5. Local cost-optimal and minimum energy performance solutions (imported PE) and their building EEM combinations for each H/C-EGS, as well as the reference case. The H/C-EGSs are in ascending order according to the dLCC of the cost-optimal solutions.

\begin{tabular}{|c|c|c|c|c|c|c|c|c|c|c|}
\hline & \multicolumn{5}{|c|}{ Local cost-optimal solutions } & \multicolumn{5}{|c|}{ Minimum energy performance solutions } \\
\hline & $\begin{array}{l}\mathrm{dLCC} \\
€ / \mathrm{m}^{2} \\
\end{array}$ & $\begin{array}{c}\mathrm{PE}_{\text {imp }} \\
\mathrm{kWh} / \\
\mathrm{m}^{2} \mathrm{a}\end{array}$ & $\begin{array}{c}\mathrm{PE}_{\text {Exp }} \\
\mathrm{kWh} / \\
\mathrm{m}^{2} \mathrm{a}\end{array}$ & $\begin{array}{c}\text { EEM } \\
\text { [wall, win, } \\
\text { inf, BSSP] }\end{array}$ & $\begin{array}{c}\mathrm{PV} \text { area } \\
\text { to reach } \\
\text { NZEB } \\
\mathrm{m}^{2}\end{array}$ & $\begin{array}{l}\mathrm{dLCC} \\
€ / \mathrm{m}^{2} \\
\end{array}$ & $\begin{array}{c}\mathrm{PE}_{\text {imp }} \\
\mathrm{kWh} / \\
\mathrm{m}^{2} \mathrm{a}\end{array}$ & $\begin{array}{c}\mathrm{PE}_{\text {Exp }} \\
\mathrm{kWh} / \\
\mathrm{m}^{2} \mathrm{a}\end{array}$ & $\begin{array}{c}\text { EEM } \\
\text { [wall, win, } \\
\text { inf, BSSP] }\end{array}$ & $\begin{array}{c}\text { PV area } \\
\text { to reach } \\
\text { NZEB } \\
\mathrm{m}^{2}\end{array}$ \\
\hline Ref. case & 0 & 162 & 0 & {$[1,1,1,1]$} & 4484 & - & - & - & - & - \\
\hline GSHP-GC & -83 & 107 & 0 & {$[1,1,1,2]$} & 2946 & -59 & 99 & 0 & {$[3,4,4,3]$} & 2733 \\
\hline PB-VCR & -82 & 117 & 0 & {$[1,1,1,2]$} & 3233 & -62 & 108 & 0 & {$[3,4,4,3]$} & 2971 \\
\hline DH-VCR & -73 & 121 & 0 & {$[1,1,1,2]$} & 3347 & -58 & 110 & 0 & {$[3,4,4,3]$} & 3047 \\
\hline ORC-VCR & -55 & 113 & 6 & {$[2,2,4,2]$} & 3127 & -37 & 109 & 5 & {$[3,4,4,3]$} & 3000 \\
\hline SE-VCR & -49 & 112 & 8 & {$[2,2,4,2]$} & 3101 & -32 & 108 & 6 & {$[3,4,4,3]$} & 2977 \\
\hline PB-AC & -39 & 121 & 0 & {$[2,2,1,2]$} & 3330 & -19 & 113 & 0 & {$[3,4,4,3]$} & 3116 \\
\hline DH-DC & -36 & 119 & 0 & {$[2,2,1,2]$} & 3280 & -22 & 109 & 0 & {$[3,4,4,3]$} & 3016 \\
\hline NG-ICE-VCR & 7 & 153 & 20 & {$[2,2,4,2]$} & 4212 & 12 & 140 & 16 & {$[3,4,4,3]$} & 3870 \\
\hline IFGT-VCR & 16 & 115 & 17 & {$[2,2,4,2]$} & 3183 & 33 & 110 & 14 & {$[3,4,4,3]$} & 3033 \\
\hline ICE-VCR & 22 & 121 & 17 & {$[2,2,4,2]$} & 3332 & 49 & 114 & 14 & {$[3,4,4,3]$} & 3154 \\
\hline ORC-AC & 45 & 119 & 10 & {$[2,2,1,2]$} & 3283 & 65 & 110 & 7 & {$[3,4,4,3]$} & 3036 \\
\hline NG-mT-VCR & 59 & 157 & 31 & {$[2,4,4,3]$} & 4321 & 62 & 156 & 30 & {$[3,4,4,3]$} & 4297 \\
\hline SE-AC & 59 & 117 & 12 & {$[2,2,1,2]$} & 3224 & 79 & 108 & 9 & {$[3,4,4,3]$} & 2981 \\
\hline D-ICE-VCR & 74 & 157 & 26 & {$[2,4,4,3]$} & 4322 & 77 & 156 & 25 & {$[3,4,4,3]$} & 4297 \\
\hline
\end{tabular}




\begin{tabular}{|l|l|l|l|l|l|l|l|l|l|l|}
\hline IFGT-AC & 232 & 126 & 34 & {$[2,2,1,2]$} & 3474 & 251 & 115 & 26 & {$[3,4,4,3]$} & 3183 \\
\hline ICE-AC & 237 & 136 & 34 & {$[2,2,1,2]$} & 3755 & 252 & 124 & 26 & {$[3,4,4,3]$} & 3416 \\
\hline
\end{tabular}

Table 6. The local cost-optimal and minimum imported $\mathrm{CO}_{2}$-eq emission solutions and their building EEM combinations for each H/C-EGS, as well as the reference case. The H/C-EGSs are in ascending order according to the dLCC of the costoptimal solutions.

\begin{tabular}{|c|c|c|c|c|c|c|c|c|}
\hline & \multicolumn{4}{|c|}{ Local cost-optimal solutions } & \multicolumn{4}{|c|}{ Minimum energy performance solutions } \\
\hline & $\begin{array}{c}\mathrm{dLCC} \\
€ / \mathrm{m}^{2}\end{array}$ & $\begin{array}{c}\mathrm{CO}_{2 \text {-eq imp }} \\
\mathrm{kg} / \mathrm{m}^{2} \mathrm{a}\end{array}$ & $\begin{array}{c}\mathrm{CO}_{2 \text {-eq Exp }} \\
\mathrm{kg} / \mathrm{m}^{2} \mathrm{a}\end{array}$ & $\begin{array}{c}\text { EEM } \\
\text { [wall, win, } \\
\text { inf, BSSP] }\end{array}$ & $\begin{array}{c}\mathrm{dLCC} \\
€ / \mathrm{m}^{2}\end{array}$ & $\begin{array}{c}\mathrm{CO}_{2 \text {-eq imp }} \\
\mathrm{kg} / \mathrm{m}^{2} \mathrm{a}\end{array}$ & $\begin{array}{c}\mathrm{CO}_{2 \text {-eq Exp }} \\
\mathrm{kg} / \mathrm{m}^{2} \mathrm{a}\end{array}$ & $\begin{array}{c}\text { EEM } \\
\text { [wall, win, } \\
\text { inf, BSSP] }\end{array}$ \\
\hline Ref. case & 0 & 33.8 & 0 & {$[1,1,1,1]$} & - & - & - & - \\
\hline GSHP-GC & -83 & 16.9 & 0.0 & {$[1,1,1,2]$} & -59 & 15.7 & 0.0 & {$[3,4,4,3]$} \\
\hline PB-VCR & -82 & 15.8 & 0.0 & {$[1,1,1,2]$} & -68 & 15.0 & 0.0 & {$[2,4,2,3]$} \\
\hline DH-VCR & -73 & 22.8 & 0.0 & {$[1,1,1,2]$} & -58 & 19.9 & 0.0 & {$[3,4,4,3]$} \\
\hline ORC-VCR & -55 & 15.2 & 1.0 & {$[2,2,4,2]$} & -44 & 14.7 & 1.0 & {$[2,4,2,3]$} \\
\hline SE-VCR & -49 & 15.1 & 1.2 & {$[2,2,4,2]$} & -39 & 14.7 & 1.2 & {$[2,4,2,3]$} \\
\hline PB-AC & -39 & 14.8 & 0.0 & {$[2,2,1,2]$} & -27 & 14.2 & 0.0 & {$[2,4,2,3]$} \\
\hline DH-DC & -36 & 23.1 & 0.0 & {$[2,2,1,2]$} & -22 & 20.6 & 0.0 & {$[3,4,4,3]$} \\
\hline NG-ICE-VCR & 7 & 30.9 & 3.2 & {$[2,2,4,2]$} & 12 & 27.7 & 2.5 & {$[3,4,4,3]$} \\
\hline IFGT-VCR & 16 & 14.8 & 2.8 & {$[2,2,4,2]$} & 27 & 14.4 & 2.8 & {$[2,4,2,3]$} \\
\hline ICE-VCR & 22 & 14.9 & 2.8 & {$[2,2,4,2]$} & 32 & 14.5 & 2.8 & {$[2,4,2,3]$} \\
\hline ORC-AC & 45 & 13.6 & 1.6 & {$[2,2,1,2]$} & 65 & 13.1 & 1.1 & {$[3,4,4,3]$} \\
\hline NG-mT-VCR & 59 & 32.2 & 4.8 & {$[2,4,4,3]$} & 62 & 32.0 & 4.7 & {$[3,4,4,3]$} \\
\hline SE-AC & 59 & 13.4 & 2.0 & {$[2,2,1,2]$} & 84 & 12.9 & 1.7 & {$[3,1,4,3]$} \\
\hline D-ICE-VCR & 74 & 32.2 & 4.1 & {$[2,4,4,3]$} & 77 & 32.0 & 4.0 & {$[3,4,4,3]$} \\
\hline IFGT-AC & 232 & 13.4 & 5.4 & {$[2,2,1,2]$} & 247 & 12.8 & 4.2 & {$[2,4,4,3]$} \\
\hline ICE-AC & 237 & 13.6 & 5.4 & {$[2,2,1,2]$} & 248 & 13.0 & 4.2 & {$[2,4,4,3]$} \\
\hline
\end{tabular}

Table A. 1 External wall insulation levels and its cost

\begin{tabular}{|l|l|l|l|l|l|}
\hline Wall insulation & Material & $\begin{array}{l}\text { Insulation } \\
\text { thickness }(\mathrm{m})\end{array}$ & $\begin{array}{l}\mathrm{U} \text {-values } \\
\left(\mathrm{W} / \mathrm{m}^{2} \mathrm{~K}\right)\end{array}$ & $\begin{array}{l}\text { Investment } \\
\operatorname{cost}\left(€ / \mathrm{m}^{3}\right)\end{array}$ & Ref. \\
\hline Wall 1 & & 0.24, & 0.17, & & \\
Wall 2 & Mineral wool & 0.35, & 0.12, & 64 & [27] \\
Wall 3 & & 0.54 & 0.09 & & \\
\hline
\end{tabular}

Table A. 2 Window types

\begin{tabular}{|l|l|l|l|l|l|l|}
\hline $\begin{array}{l}\text { Window } \\
\text { no }\end{array}$ & $\begin{array}{l}\text { U-value } \\
\left(\mathrm{W} / \mathrm{m}^{2} \mathrm{~K}\right)\end{array}$ & T-value & SHGC & $\begin{array}{l}\text { Cost } \\
\left(€ / \mathrm{m}^{2}\right)\end{array}$ & Description & Ref. \\
\hline${\text { Win } 1^{\text {a }}}^{1.0}$ & 0.56 & 0.68 & 250 & Triple-laminated glass wood aluminum (Argon gas) & {$[4]$} \\
\hline
\end{tabular}




\begin{tabular}{|l|l|l|l|l|l|l|}
\hline Win 2 $^{\mathrm{a}}$ & 1.0 & 0.34 & 0.46 & 258 & Triple-laminated glass wood aluminum (Argon gas) & {$[8]$} \\
\hline Win 3 & 0.85 & 0.29 & 0.42 & 290 & $\begin{array}{l}\text { Quadruple-laminated glass wood aluminum (Krypton } \\
\text { gas) }\end{array}$ & {$[4]$} \\
\hline Win 4 $^{\mathrm{a}}$ & 0.7 & 0.2 & 0.3 & 350 & $\begin{array}{l}\text { Quadruple-laminated glass wood aluminum (Krypton } \\
\text { gas) }\end{array}$ & [4] \\
\hline
\end{tabular}

${ }^{\mathrm{a}}$ In all windows, the blinds are between the outer panels.

The worker cost is subtracted from the total cost of windows taken from [4] to be only the investment cost.

Table A. 3 Infiltration levels

\begin{tabular}{|l|l|l|}
\hline Infiltration level & Specification $\mathrm{n} 50(1 / \mathrm{h})$ & Additional labor cost $\left(€ / \mathrm{m}^{2}\right.$ of envelope $)$ \\
\hline Inf 1 & 1.0 & 0.0 \\
\hline Inf 2 & 0.74 & 4.15 \\
\hline Inf 3 & 0.49 & 8.3 \\
\hline Inf 4 & 0.37 & 9.6 \\
\hline
\end{tabular}

Costs are taken from [7] and updated to 2013 ones by using $3.2 \%$ inflation rate [28]

Table A. 4 Building service system packages of ventilation system, daylight control [4]

\begin{tabular}{|c|c|c|c|}
\hline System packages & BSSP 1 & BSSP 2 & BSSP 3 \\
\hline \multicolumn{4}{|l|}{ AHU \#1 } \\
\hline Heat recovery effectiveness ${ }^{\text {a }}$ & 0.6 & 0.8 & 0.8 \\
\hline Maximum allowable exhaust air temperature & 4.0 & 1.0 & 1.0 \\
\hline Ventilation control & CAV & VAV $^{\mathrm{c}}$ & VAV $^{\mathrm{c}}$ \\
\hline Air flow rates of $\mathrm{L} / \mathrm{s}, \mathrm{m}^{2}$ & 1.85 & $\begin{array}{l}\min 0.07 \\
\max 1.85\end{array}$ & $\begin{array}{l}\min 0.07 \\
\max 1.85\end{array}$ \\
\hline Specific fan power (SFP) $\mathrm{kW} /\left(\mathrm{m}^{3} / \mathrm{s}\right)$ & 2 & 1.8 & 1.4 \\
\hline \multicolumn{4}{|l|}{ AHU \#2 } \\
\hline Heat recovery effectiveness ${ }^{\mathrm{a}, \mathrm{b}}$ & - & 0.55 & 0.55 \\
\hline Maximum allowable exhaust air temperature & 4.0 & 1.0 & 1.0 \\
\hline Air flow rate (constant flow), $\mathrm{L} /\left(\mathrm{s} . \mathrm{m}^{2}\right)$ & 0.15 & 0.15 & 0.15 \\
\hline Ventilation control & CAV & CAV & CAV \\
\hline Specific fan power (SFP) & 2 & 1.8 & 1.4 \\
\hline Total ventilation system cost $\left(€ / \mathrm{m}^{2}\right)$ & 90 & 110 & 115 \\
\hline Daylight control (Yes/No) & No & Yes $^{\mathrm{d}}$ & Yes $^{\mathrm{d}}$ \\
\hline Building automation cost $\left(€ / \mathrm{m}^{2}\right)$ & 10 & 15 & 15 \\
\hline
\end{tabular}

${ }^{\mathrm{a}}$ Supply air heat recovery ratio

${ }^{\mathrm{b}}$ AHU \#2 serves services zones, corridors, toilets, atrium, etc.

${ }^{\mathrm{c}}$ The ventilation control of VAV limits: minimum $<600 \mathrm{ppm}$ and up to $>900 \mathrm{ppm}$.

${ }^{\mathrm{d}}$ Daylight control limits: <500 lx illumination a fully enabled, $>700$ lx lighting off completely.

Table B. 1 District heating and district cooling costs for business customer

\begin{tabular}{|l|l|l|l|l|}
\hline System & Thermal capacity $(\mathrm{kW})$ & Installation cost $(€)$ & $\begin{array}{l}\text { annual subscription } \\
\text { fees }(€)\end{array}$ & Ref. \\
\hline DH & $61>\mathrm{Q}_{\mathrm{h}}>190$ & 15500 & $22.7 \mathrm{Q}_{\mathrm{h}}+2753.73$ & {$[30]$} \\
\hline & $191>\mathrm{Q}_{\mathrm{h}}>350$ & 24800 & $22.7 \mathrm{Q}_{\mathrm{h}}+2753.73$ & \\
\hline
\end{tabular}




\begin{tabular}{|l|l|l|l|l|}
\hline $\mathrm{DC}$ & $220>\mathrm{Q}_{\mathrm{c}}>315$ & $372 \times \mathrm{Q}_{\mathrm{c}}$ & $58.28 \mathrm{Q}_{\mathrm{c}}$ & \\
\hline
\end{tabular}

$\mathrm{Q}_{\mathrm{h}}$ is thermal heating capacity.

$\mathrm{Q}_{\mathrm{c}}$ is thermal cooling capacity.

The fixed annual fees are service and subscription cost.

Table B. 2 Pellet boiler costs

\begin{tabular}{|l|l|l|l|l|}
\hline $\begin{array}{l}\text { Thermal heating } \\
\text { capacity }(\mathrm{kW})\end{array}$ & $\begin{array}{l}\text { Thermal efficiency } \\
(\%)\end{array}$ & Installation cost $(€)$ & $\begin{array}{l}\text { Annual operation and } \\
\text { maintenance }(\mathrm{O} \& \mathrm{M})(€)\end{array}$ & Ref. \\
\hline $100<\mathrm{Q}_{\mathrm{h}}<200$ & $84.0^{\mathrm{a}}$ & 85,000 & 2,100 & \\
\hline $200<\mathrm{Q}_{\mathrm{h}}<350$ & $84.0^{\mathrm{a}}$ & 100,000 & 2,100 & \\
\hline $350<\mathrm{Q}_{\mathrm{h}}<600$ & $84.0^{\mathrm{a}}$ & 130,000 & 2,100 & \\
\hline
\end{tabular}

${ }^{\mathrm{a}}$ annual average efficiency based on Finnish building code D5-2012 [6]

Table B. 3 GSHP performance and costs

\begin{tabular}{|l|l|l|l|}
\hline Item & cost & unit & Ref. \\
\hline Boreholes drilling & 33.45 & $€ / \mathrm{m}$ & \multirow{2}{*}{ [32] } \\
\hline Piping of the ground heat exchanger & 15 & $€ / \mathrm{m}^{2}$ of gross building area & \\
\hline Heat pump equipment & 325 & $€ / \mathrm{kW}$ & \\
\hline
\end{tabular}

- Annual average COP of the GSHP for space and ventilation heating is 3.0 and for DHW is 2.3 based on Finnish building code D5-2012 [6]

- The annual O\&M costs are assumed to be $1.5 \%$ of installation cost.

- The optimal borehole lengths required for both heating and free ground cooling purposes of the 144 building combinations are obtained using EED 3 (Earth Energy Designer) software [34].

Table B. 4 Vapor compression refrigeration (VCR) cooling system and absorption chiller system performance and costs

\begin{tabular}{|l|l|l|l|l|}
\hline System & COP & Installation cost $(€)$ & Annual O\&M $(€)$ & Ref. \\
\hline $\begin{array}{l}\text { Vapor compression refrigeration } \\
\text { (VCR) cooling system }\end{array}$ & $3.0^{\mathrm{a}}$ & 72020 & 620 & {$[33]$} \\
\hline Absorption chiller (AC) system & $0.7^{\mathrm{a}}$ & 133578 & $\begin{array}{l}\text { Every year }=3000^{\mathrm{b}} \\
\text { Every 3 years }=50000^{\mathrm{c}} \\
\text { After 10 years }=15000^{\mathrm{d}}\end{array}$ & {$[33]$} \\
\hline
\end{tabular}

\footnotetext{
${ }^{a}$ Annual average coefficients of performance are based on [6]

${ }^{\mathrm{b}}$ The annual O\&M includes checks and solution sample analysis.

${ }^{\mathrm{c}}$ Every 3 years O\&M includes change rupture disc.

${ }^{\mathrm{d}}$ After 10 years O\&M includes change the solution pump and refrigerant pump, (the price is assumed).
} 
Table B. 5 CHPs technologies' characteristics and costs

\begin{tabular}{|c|c|c|c|c|c|c|c|c|c|c|c|}
\hline Technologies & Fuel & $\begin{array}{l}\text { Electrical } \\
\text { efficiency } \\
\eta_{\mathrm{e}} \%\end{array}$ & $\begin{array}{l}\text { Thermal } \\
\text { efficiency } \\
\eta_{\text {th }} \%\end{array}$ & $\begin{array}{l}\text { Overall } \\
\text { efficiency } \\
\eta_{\text {ov }} \%\end{array}$ & $\begin{array}{l}\text { Power to } \\
\text { heat ratio } \\
\mathrm{P}_{\mathrm{e}} / \mathrm{H}_{\mathrm{th}}\end{array}$ & $\begin{array}{l}\text { Life- } \\
\text { time } \\
\text { (year) }\end{array}$ & $\begin{array}{l}\text { Inv. cost } \\
\left(€ / \mathrm{kW}_{\mathrm{e}}\right)\end{array}$ & $\begin{array}{l}\text { Variable } \\
\text { O\&M } \\
\left(€ / \mathrm{kWh}_{\mathrm{e}}\right)\end{array}$ & $\begin{array}{l}\text { Fixed } \\
\text { O\&M } \\
\left(€ /\left(\mathrm{kW}_{\mathrm{e}} \mathrm{a}\right)\right.\end{array}$ & Ref. & Electrical capacity range \\
\hline ORC & Pellets & $14^{\mathrm{a}}$ & $70^{a}$ & $85^{\mathrm{a}}$ & $0.2^{\mathrm{a}}$ & $20^{b}$ & $6696^{c}$ & $0.0072^{\mathrm{d}}$ & $135^{\mathrm{d}}$ & $\begin{array}{l}\mathrm{a}, \mathrm{c}[12], \\
\mathrm{b}[36], \\
\mathrm{d}[36]\end{array}$ & $\begin{array}{l}\text { with VCR } 30-90 \mathrm{kWe} \\
\text { with AC } 78-114 \mathrm{kWe}\end{array}$ \\
\hline Gasifier, ICE & Pellets & $23^{\mathrm{e}}$ & $46^{\mathrm{e}}$ & $70^{\mathrm{e}}$ & $0.5^{\mathrm{e}}$ & $20^{f}$ & $5987^{\mathrm{g}}$ & $0.037^{\mathrm{h}}$ & $147^{h}$ & $\begin{array}{l}\text { e }[12], \\
\text { f }[36] \\
\mathrm{g}, \mathrm{h}[37]\end{array}$ & $\begin{array}{l}\text { with VCR } 75-225 \mathrm{kWe} \\
\text { with AC } 195-285 \\
\mathrm{kWe}\end{array}$ \\
\hline $\begin{array}{l}\text { Direct } \\
\text { combustion } \\
\text { IFGT }\end{array}$ & Pellets & $28^{\mathrm{i}}$ & $56^{i}$ & $84^{\mathrm{i}}$ & $0.5^{\mathrm{i}}$ & $20^{j}$ & $6800^{k}$ & $0.024^{1}$ & $131^{1}$ & $\begin{array}{l}\mathrm{i}[35], \\
\mathrm{j}[12], \\
\mathrm{k}, \mathrm{l}[37]\end{array}$ & $\begin{array}{l}\text { with VCR } 75-225 \mathrm{kWe} \\
\text { with AC } 195-285 \\
\mathrm{kWe}\end{array}$ \\
\hline $\begin{array}{l}\text { Updraft } \\
\text { gasifier SE }\end{array}$ & Pellets & $18^{\mathrm{m}}$ & $72^{m}$ & $90^{\mathrm{m}}$ & $0.24^{\mathrm{m}}$ & $20^{n}$ & $7652^{m}$ & $0.032^{n}$ & $33^{n}$ & $\begin{array}{l}\frac{\mathrm{m}}{\mathrm{m}}[12], \\
\mathrm{n}[35]\end{array}$ & $\begin{array}{l}\text { with VCR } 36-108 \mathrm{kWe} \\
\text { with AC } 94-137 \mathrm{kWe}\end{array}$ \\
\hline $\begin{array}{l}\text { Natural Gas } \\
\text { ICE }\end{array}$ & NG & 25.1 & 44.4 & 69.5 & 0.56 & 20 & 1436 & 0.016 & $20+37.3^{p}$ & [37] & with VCR $85-254 \mathrm{kWe}$ \\
\hline $\begin{array}{l}\text { Micro- } \\
\text { turbine }\end{array}$ & NG & 31 & 34 & 65 & 0.97 & 20 & 1946 & 0.005 & $60+37.3^{p}$ & [37] & $\begin{array}{l}\text { with VCR } 146-427 \\
\text { kWe }\end{array}$ \\
\hline Diesel ICE & Diesel & 28.4 & 33.4 & 61.8 & 0.85 & 20 & 1439 & 0.016 & 7 & [37] & $\begin{array}{l}\text { with VCR } 129-385 \\
\text { kWe }\end{array}$ \\
\hline
\end{tabular}

${ }^{\mathrm{a}-\mathrm{n}}$ The references of all data are identified separately using superscripts.

${ }^{\mathrm{p}}$ The first value is the unit fixed annual O\&M, while the second one is the annual gas grid subscription fee [30]. 
Table C. 1 Specifications of the PV module "210 P2 PBW" [46] inputted into TRNSYS software to get the hourly electricity production

\begin{tabular}{|c|c|}
\hline Parameter & Value \\
\hline $\operatorname{Area}\left(\mathrm{m}^{2}\right)$ & 1.444 \\
\hline Cell type & polycrystalline \\
\hline \multicolumn{2}{|l|}{ Performance at STC } \\
\hline Maximum power (W/Pmax) & 210 \\
\hline Maximum power tolerance $(\mathrm{W})$ & $+5 /-0$ \\
\hline Current (typical at max power) $\left(\mathrm{A} / \mathrm{I}_{\mathrm{p}}\right)$ & 8.16 \\
\hline Voltage (typical at max power) $\left(\mathrm{V} / \mathrm{V}_{\mathrm{p}}\right)$ & 25.8 \\
\hline Short circuit current (typical) $\left(\mathrm{A} / \mathrm{I}_{\mathrm{sc}}\right)$ & 8.77 \\
\hline Open circuit voltage (typical) $\left(\mathrm{V} / \mathrm{V}_{\mathrm{oc}}\right)$ & 33.3 \\
\hline Module efficiency (minimum) (\%) & 14.5 \\
\hline Module efficiency (maximum) (\%) & 14.9 \\
\hline \multicolumn{2}{|l|}{ Performance at NOCT } \\
\hline Maximum power (W/Pmax) & 151.3 \\
\hline Current (typical at max power) $\left(\mathrm{A} / \mathrm{I}_{\mathrm{p}}\right)$ & 6.46 \\
\hline Voltage (typical at max power) $\left(\mathrm{V} / \mathrm{V}_{\mathrm{p}}\right)$ & 23.4 \\
\hline Short circuit current (typical) $\left(\mathrm{A} / \mathrm{I}_{\mathrm{sc}}\right)$ & 7.09 \\
\hline Open circuit voltage (typical) $\left(\mathrm{V} / \mathrm{V}_{\mathrm{oc}}\right)$ & 30.5 \\
\hline \multicolumn{2}{|l|}{ Temperature Coefficients at STC type } \\
\hline Open circuit voltage $(\mathrm{V} / \mathrm{K})$ & -0.117 \\
\hline Short circuit current $(\mathrm{A} / \mathrm{K})$ & 0.0040 \\
\hline Maximum power $(\% / \mathrm{K})$ & -0.54 \\
\hline Efficiency Reduction from STC Reduction (approximately) (\%) & 5 \\
\hline
\end{tabular}

STC $=$ Standard Test Conditions; cell temperature $=25^{\circ} \mathrm{C}$, irradiation $=1000 \mathrm{~W} / \mathrm{m}^{2}$, air mass $=1.5$.

NOCT $=$ Normal operating cell temperature; cell temperature $=46{ }^{\circ} \mathrm{C}$, irradiation $=800 \mathrm{~W} / \mathrm{m}^{2}$, ambient temperature $=20$

${ }^{\circ} \mathrm{C}$, wind speed $<=1.0$. 